\title{
Larval fish distribution and retention in the Canary Current system during the weak upwelling season
}

\author{
M. MOYANO, ${ }^{1,4, *}$ J.M. RODRÍGUEZ, ${ }^{2}$ V.M. \\ BENÍTEZ-BARRIOS ${ }^{1,3}$ AND S. HERNÁNDEZ- \\ LEÓN $^{1}$ \\ ${ }^{1}$ Instituto de Oceanografía y Cambio Global, Universidad de Las \\ Palmas de Gran Canaria, Campus Universitario de Tafira, \\ 35017, Las Palmas de Gran Canaria, Canary Islands, Spain \\ ${ }^{2}$ Centro Oceanográfico de Gijón, Instituto Español de Oceanog- \\ rafía, Avda, Príncipe de Asturias 70Bis, 33212, Gijón, Astu- \\ rias, Spain \\ ${ }^{3}$ Centro Oceanográfico de Canarias, Instituto Español de Ocean- \\ ografía, Via Espaldón, Dársena Pesquera, parcela 8, 38180, \\ Santa Cruz de Tenerife, Canary Islands, Spain
}

sometimes coexisted. Finally, larval connectivity between Islands within the Canary archipelago is suggested. The present study thus contributes to the understanding of the complex dispersal and retention processes in the Canaries-African Coastal Transition Zone. However, results also highlight the poor knowledge of this region compared with the other three main Eastern Boundary Upwelling Systems in terms of ichthyoplankton dynamics. The importance of routine monitoring programs of commercial and non-commercial species in the area is emphasized.

Key words: connectivity, larval drift, larval fish assemblages, Eastern Boundary Upwelling System

\section{INTRODUCTION}

Dispersal of the early life stages of fish may have dramatic consequences for their survival and, further, for population connectivity and recruitment success (Harden-Jones, 1968; Cowan and Shaw, 2002). To provide population closure and preserve self-recruitment, retention mechanisms have likely evolved to avoid drift to unfavourable areas. These retention mechanisms may be either passive (e.g., accumulation of larvae within eddies, Karnauskas et al., 2011) or active (e.g., diel vertical migrations, Landaeta and Castro, 2013). Understanding how these processes develop in each environment is critical for performing real estimates of larval survival within any modelling approach and/or recruitment study.

The Eastern Boundary Upwelling Systems (EBUS) constitute very productive, albeit highly dynamic regions where offshore dispersal may lead to massive losses of fish larvae (Cury and Roy, 1989; Castro and Hernandez, 2000). In terms of fish population dynamics, the Canary Current system (Fig. 1) is the least studied of these EBUS (i.e., California, Benguela and/or Humboldt). This system functions rather differently than the other three due to the presence of the Canary Islands. This archipelago acts as a $>600-\mathrm{km}$ wide barrier to the flow of the Canary Current and high mesoscale activity is thus generated south of the islands (Barton et al., 1998) (Fig. 1). Trade winds blow persistently in the area during summer (July-September), leading to the strong upwelling season on the 
African coast and also to more frequent island-generated mesoscale structures south of the Canary Islands. Mesoscale features generated in the African coast (e.g., upwelling filaments, Rodríguez et al., 1999), and south of the islands (island-wakes or eddies) can interact in the so-called Canaries-African Coastal Transition Zone (Canaries-African CTZ).

Dispersal processes in EBUS are frequent but do not necessarily imply larval losses. These processes can be linked to other concentration and retention mechanisms that lead to a high growth - low predation scenario for fish larvae: ocean triad (Bakun, 1996). For example, Ekman transport and upwelling filaments have been reported to transport fish larvae and their prey tens or hundreds of kilometers away from the coast (Parrish et al., 1981; Hutchings et al., 2002) to a lower predation pressure environment. But these filaments can also interact with other structures (e.g., eddies) that return the biogenic material back to the shelf (Bakun, 1996). In the case of the NW African upwelling, a filament-cyclonic eddy complex south of Fuerteventura (Fig. 1) has been invoked as a potential retention mechanism for clupeid larvae (Rodríguez et al., 1999; Rodríguez et al., 2004). Secondly, offshore eddies can also lead to a high-growth scenario for larvae due to increased production compared with the surrounding ocean waters (California Current, Logerwell and Smith, 2001; Canary Current, Bécognée et al., 2009). Besides these common processes observed in other EBUS (i.e., upwelling filaments and eddies), a third transport mechanism present in the CanariesAfrican CTZ is the larval transport from the African coast to the Canary Islands by upwelling filaments (Bécognée et al., 2006; Moyano et al., 2009). Connectivity among islands within the archipelago and with other archipelagos (e.g., Madeira, Cape Verde) has been suggested (Rodríguez et al., 2000; Rodríguez et al., 2004) but never observed in the field.

Besides the above-mentioned passive retention mechanisms, larval behavior can also favor coastal retention. For example, in the Humboldt Current postflexion larvae of Peruvian anchoveta perform a
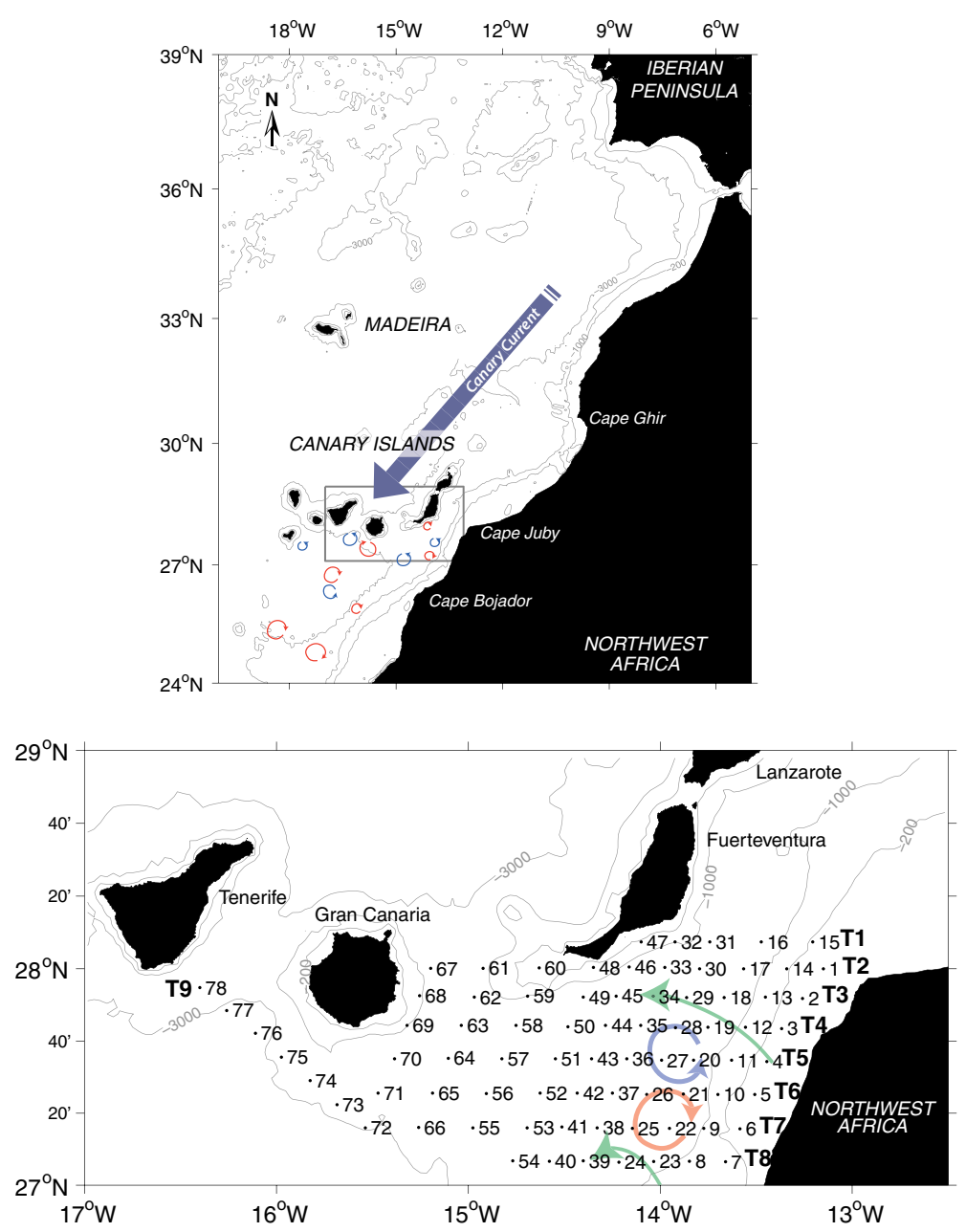

Figure 1. Map showing the location of the sampling area. The upper panel indicates the direction of the Canary Current and some mesoscale eddies formed near the NW African upwelling area and south of the Canary Islands (red: anticyclonic eddies; blue: cyclonic eddies). The lower panel displays the 78 sampling stations (zonal transects are shown as T1-T9) and four frequent mesoscale structures in the area: northern filament originated near Cape Juby (green arrow) and its associated cyclonic eddy (blue); southern filament generated near Cape Bojador (green arrow) and its associated anticyclonic eddy (red). 
diel vertical migration (DVM) from depth to shallower waters at night (Landaeta and Castro, 2013). This upwards migration at night, or Type I DVM (Neilson and Perry, 1990), prevents advection during daytime in which winds, and thus Ekman transport, is stronger. The opposite DVM, Type II DVM (Neilson and Perry, 1990), has been observed for anchovy in the Benguela system (Stenevik et al., 2007). But these authors argue that this behavior also contributes to larval transport towards the nursery areas, due to the shallow Ekman layer and the deeper onshore current. Despite the importance of vertical distribution and diel migrations for retention processes on each particular system, there have been very few studies investigating them in the NW African upwelling (John, 1985; Rodriguez et al., 2006). Given the complex hydrodynamic scenario that fish larvae face in upwelling systems in general, and in the Canaries-African CTZ in particular, understanding the fate of the larvae and quantifying their growth and survival in this environment is essential. This complexity also highlights the need to see 'the big picture', and work on a larger scale in terms of fisheries and ecosystem assessment and management.

The bulk of fishery studies done in NW African upwelling focus on stock assessment and management of the commercially important species (e.g., the Dr. Fridtjof Nansen Programme, Saetersdal et al., 1999). The small pelagic fish assemblage mainly comprises sardine (Sardina pilchardus), anchovy (Engraulis encrasicolus), horse mackerels (Trachurus spp.), and round sardinellas (Sardinella spp.) (Arístegui et al., 2009). Sardine dominates the assemblage from Gibraltar to Cape Blanc, accounting for $>70 \%$ of the annual fish catches in the region, whereas round sardinella species prevail further south (FAO, 2009). The demersal assemblage on the shelf mainly comprises sparids (Pagellus spp., Dentex spp., Sparus spp.) and, on the outer shelf, hairtails (Trichiurus lepturus) and hakes (Merluccius merluccius, Merluccius senegalensis and Merluccius polli). The mesopelagic fish community is composed primarily of lanternfishes (Myctophidae), bristlemouths (Gonostomatidae) and lightfishes (Phosichthyidae). This mesopelagic community is often disregarded, although it can represent more than half of the adult fish catches in trawl tows south of the Canary Islands (Wienerroither, 2005). In addition, recent studies suggest that the abundances of mesopelagic species might be underestimated due to net avoidance (Kaartvedt et al., 2012). Besides their potential abundance, mesopelagic fish have a key role in large ecosystems, e.g., as prey for bigger fish such as tuna, and transferring carbon to the deep sea (Davison et al., 2013). Several recent studies acknowledge that, although living in depth, these fish are also sensitive to climate-driven changes (Koslow et al., 2013). These findings thus highlight the need for continuous monitoring and management of these unexploited species, as well as the incorporation of this component in future ecosystem-based management.

The present study focuses on the ichthyoplankton community in the Canaries-African CTZ. Previous larval fish works in the area investigated the dynamics of commercial species (mainly clupeids) in the African shelf (e.g., John, 1982; Ettahiri, 1996; Arkhipov, 2009) but the transition zone has been overlooked. Only a handful studies have analyzed non-commercial species in the Canaries-African CTZ (Rodríguez et al., 1999; 2004, 2006), all cruises conducted during the strong upwelling season (summer). Our work is the first to investigate the entire larval fish community in the Canaries-African CTZ in winter-spring (during the weak upwelling season). Our aims were to (i) explore the interactions between coastal and mesopelagic species during their early life stages; (ii) understand the influence of hydrodynamic structures (upwelling front, filament, eddies) on the distribution of fish larvae; (iii) contribute to the few ichthyoplankton samplings in the area, mostly needed to improve modeling of larval dispersal (Brochier et al., 2009, 2011a) and, further, to better understand species dynamics (at early stages) in the frame of future ecosystem-based assessment and management.

\section{MATERIAL AND METHODS}

\section{Data set}

Field data were acquired on board R/V Hespérides during the scientific expedition CONAFRICA, which surveyed the NW African CTZ from 22 March to 17 April 2006 (Fig. 1). Sampling was carried out day and night at 78 stations distributed along nine transects $20 \mathrm{~km}$ apart (Fig. 1). Vertical profiles of conductivity, temperature, pressure and fluorescence were obtained using an SBE 911 plus CTD equipped with a Seapoint chlorophyll $a(\mathrm{Chl}-a)$ fluorometer. The CTD was lowered to a maximum depth of $2000 \mathrm{~m}$ and vertical profiles were binned to 2 decibars (db). Dynamic height and the geostrophic velocity vectors used in this study were calculated as described in Benítez- Barrios et al. (2011).

Ichthyoplankton was collected with a LonghurstHardy Plankton Recorder net (LHPR, Longhurst and Williams, 1976) equipped with a 200- $\mu$ m mesh size and an electronic flowmeter, to measure the volume of filtered water. Stratified tows were conducted at three knots from the surface down to $200 \mathrm{~m}$ depth or to $20 \mathrm{~m}$ above the sea bed where shallower. The $200-\mu \mathrm{m}$ 
mesh screen in the sampler was programmed to increment at 2-min intervals during the descent of the net. Ten samples ( $20 \mathrm{~m}$ vertical resolution) were obtained from each haul. The mean volume of water filtered by the net in each sample was $20.75 \pm 0.35 \mathrm{~m}^{3}$. Samples were stored in a $4 \%$ buffered solution of formalin and seawater for further taxonomic analysis in the laboratory.

Once in the laboratory, fish larvae were sorted and identified to the lowest taxonomic level possible. Only S. pilchardus and E. encrasicolus eggs were identified. The number of eggs and larvae collected in the different strata was standardized to number of individuals by unit of volume $\left(1000 \mathrm{~m}^{3}\right)^{-1}$, densities, and then integrated at every station to obtain the number of individuals $\left(10 \mathrm{~m}^{2}\right)^{-1}$, abundances (Smith and Richardson, 1977). Unfortunately, most larvae were slightly or moderately damaged, which prevented us from performing length measurements.

The Greenwood classification (CLOFETA, Queró et al., 1990) was used for the taxonomic organization of fish larvae. Following Rodríguez et al. (1999), larvae were divided into three categories (Neritic, Oceanic and Other) according to the habitat and reproductive region of the adults.

\section{Data analysis}

Similarities among stations, using environmental factors (depth, temperature at $10 \mathrm{~m}$, salinity at $10 \mathrm{~m}$ and average fluorescence from 5 to $100 \mathrm{~m}$ ) as variables, were assessed using hierarchical clustering and principal component analysis (PCA) on the Euclidean-distance matrix generated from normalized data (depth-samples averaged across stations).

Horizontal and vertical distribution of total larvae and of the eight most abundant genera was analyzed. Depth strata used for analysis of vertical distribution and diel vertical migration were: $0-20,20-35,35-55$, $55-80,80-105,105-130,130-155,155-175,175-$ $200 \mathrm{~m}$. Differences in abundance among depth strata were analyzed with a Kruskal-Wallis analysis of variance (K-W ANOVA). The weighted mean depths (WMD) of larvae in each haul were calculated as the center of masses of larval distribution:

$$
\mathrm{WMD}=\sum_{i=1}^{n} p_{i} Z_{i}=\frac{\sum_{i=1}^{n} C_{i} Z_{i}}{\sum_{i=1}^{n} C_{i}}
$$

where $p_{i}$ and $\mathrm{C}_{i}$ are the proportion and concentration of fish larvae [ind. $\left(1000 \mathrm{~m}^{3}\right)^{-1}$ ] in the $i$-th stratum, and $Z_{i}$ is the mid-depth of the $i$-th stratum (e.g., Fortier and Leggett, 1983; Rodriguez et al., 2006). The amplitude of diel vertical migrations (DVM) was calculated as the difference between the day and night average WMD $\left(\mathrm{DVM}=W M D_{\text {night }}-W M D_{\text {day }}\right)$. Positive values of DVM (DVM type I) correspond to species that move towards the surface during the night, whereas negative values indicate downwards movement at night (DVM type II) (Neilson and Perry, 1990). Finally, a Student's t-test was applied to test for significance of the DVM.

The structure of the larval fish community was studied using multivariate analysis. Hierarchical agglomerative cluster analysis in conjunction with non-metric multidimensional scaling (MDS) ordination were used to identify taxa and station assemblages (Field et al., 1982). Due to the small size of larvae or to damages associated to the LHPR functioning ('sample sandwiching'), an important number of larvae of mesopelagic species (e.g., Vinciguerria, Cyclothone) were only identified to generic level. In addition, most of the abundant genera in this study are monospecific (e.g., Sardina, Engraulis, Diogenichthys). Moreover, considering that analyses at the genus level could be a good proxy for species in the analysis of larval assemblages (Hernandez et al., 2013), genera, instead of species, were used in the community analysis. To avoid the noise-derived effects from rare genera, only those present in at least eight sampling stations ( $10 \%$ of all stations) and contributing $>0.90 \%$ to total larval abundance were included in the analysis (18 genera, $68.29 \%$ of total collected larvae). Prior to building the similarity matrix using the Bray-Curtis index, genus abundance data were $\log _{10}(\mathrm{x}+1)$-transformed to reduce the influence of abundant taxa. Hierarchical agglomerative clustering was then conducted on the genus resemblance matrix averaged across stations or depths, using group-average linkages to find natural groupings of samples. Arbitrary cut-off levels were chosen on dendrograms to produce ecologically interpretable clusters (Field et al., 1982; Auth and Brodeur, 2006).

The adequacy of the groups was assessed by two-dimensional (2D) non-metric multidimensional scaling (nMDS) ordination. The contribution of individual taxa to each cluster group was assessed with the similarity percentages routine (SIMPER). The ratio between the taxa contribution to the average dissimilarity among groups and the standard deviation (Diss/ SD) was used to identify key species. Finally, the BEST (Bio-Env) routine was performed to find the best match between multivariate among-sample patterns of larval assemblages and environmental variables associated to those samples.

All the above univariate and multivariate statistical analyses were carried out with STATISTICA 7.1 
(StatSoft, 2005) and PRIMER 6.1.6 (Plymouth Routines In Multivariate Ecological Research) statistical packages, respectively.

\section{RESULTS}

\section{Hydrographic conditions}

The hydrography of the study area during the cruise has been thoroughly described in Benítez-Barrios et al. (2011). NE winds prevailed during March and early April (QuickSCAT, http://www.ifremer.fr/cersat/), leading to upwelling favorable conditions. During the cruise, cold and productive waters near the African coast contrasted with the warmer and oligotrophic waters in the open ocean (Fig. 2). The main hydrographic feature found was a frontal system, which divided the sampling area into three regions: upwelling, frontal and offshore. These regions were well differentiated in the geostrophic velocity field (Fig. 2a) and bounded by the dynamic height isolines of 0.625 and 0.640 dyn at $20 \mathrm{~m}$ (Fig. 2b). The frontal area, with a width of about $30 \mathrm{~km}$, had an associated meandering jet that was largely invariant down to $245 \mathrm{~m}$ depth. According to Benítez-Barrios et al. (2011), the

Figure 2. (a) Horizontal distribution of potential temperature $\left({ }^{\circ} \mathrm{C}\right)$ and geostrophic currents at $20 \mathrm{~m}$ depth. (b) SeaWiFS satellite images from 7 April 2006 showing the horizontal distribution of sea-surface chlorophyll concentration. Superimposed is the location of relevant mesoscale structures (filaments F1 and F2, cyclonic eddy C1 and anticyclonic eddy A1) and the dynamic height contours at $20 \mathrm{~m}$ of 0.625 and 0.64 dyn $\mathrm{m}$.
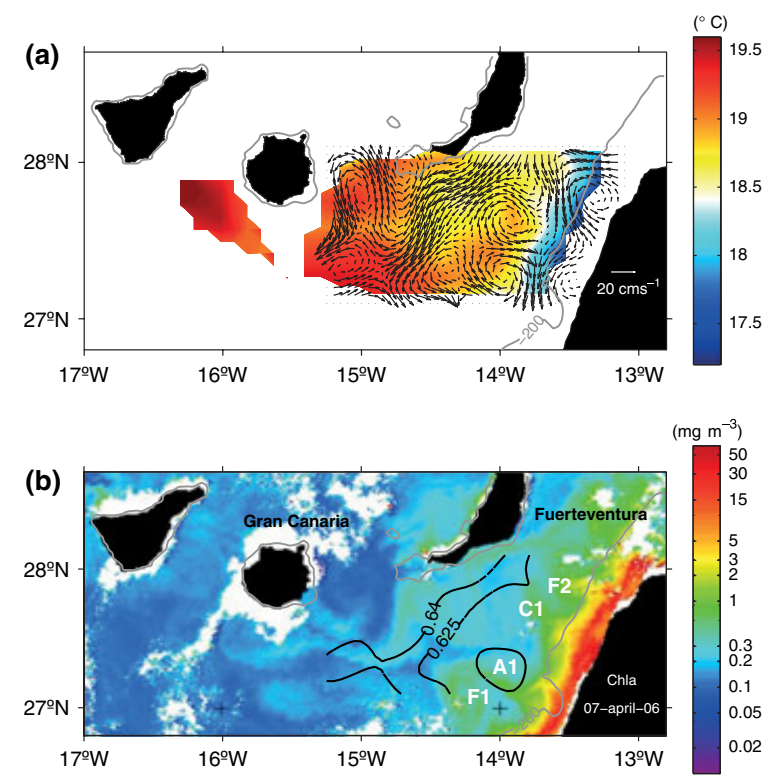

offshore extreme of the upwelling area was determined by the $17.4^{\circ} \mathrm{C}$ isotherm at $110 \mathrm{~m}$.

Mesoscale activity was substantial during the period studied, generating a dynamic and complex hydrographic scenario influencing larval distributions. In the upwelling area, a tongue of cold $\left(<19^{\circ} \mathrm{C}\right)$, fresh $(<36.7)$ water was found near-surface $(10 \mathrm{~m}$ depth), but it faded in the first $50 \mathrm{~m}$. In addition, two filaments appeared, F1 associated with anticyclonic eddy (A1) and $\mathrm{F} 2$ associated with a cyclonic eddy $(\mathrm{C} 1)$, stretching from Cape Bojador and Cape Juby, respectively (Fig. 2b). The C1-A1 dipole produced an onshore flow inbetween. Besides C1 eddy, several other shallow baroclinic eddies (e.g., anticyclone centered in station 13) were present in the upwelling area, probably originated by instabilities of the baroclinic jet associated with the upwelling front. Although the isotherm and fluorescence slopes to $200 \mathrm{~m}$ both preclude a clear identification of A1 and that centered in station 13, they are clearly visible in the potential temperature and velocity distribution down to $500 \mathrm{~m}$ (Fig. $7-11$ in Benítez-Barrios et al., 2011). On the other hand, some eddies found in the offshore region (e.g., anticyclonic and cyclonic eddies SW of Fuerteventura Island, centered in stations 59 and 62, respectively) were deep barotropic eddies, suggesting an island origin.

Hierarchical group-average clustering of environmental variables (bottom depth, temperature, salinity, fluorescence) grouped sampling stations into a coastal and an oceanic group at a Euclidean distance of 3 (Fig. 3a). PCA analysis confirmed the cluster results (Fig. 3b). The coastal group included shallow stations, characterized by cold, less saline and chlorophyll-rich waters. Oceanic stations were located in warmer, saltier and less productive offshore waters. PC1 explained $76.4 \%$ of the variability of the stations, since all variables showed high eigenvector values, with the opposite direction to fluorescence (Table 1). PC2 explained $15.3 \%$ of the variability and was mainly composed of fluorescence.

\section{Taxonomic composition of the larval fish community}

A total of 3248 fish larvae were collected during this cruise (Table 2). Oceanic larvae accounted for $60.1 \%$ of total larval catches (TLC), whereas neritic larvae contributed $18.3 \%$. Due to the damage caused by the LHPR, as already mentioned, $21.6 \%$ of collected larvae could not be identified.

Myctophidae and Phosichthydae were the most abundant families $(20.7 \%$ and $19.9 \%$ TLC, respectively). Among neritic families, Clupeidae, Carangidae and Engraulidae dominated neritic larval catches (5.9, 5.0 and $3.4 \%$ TLC, respectively). The most

(C) 2014 John Wiley \& Sons Ltd, Fish. Oceanogr., 23:3, 191-209. 

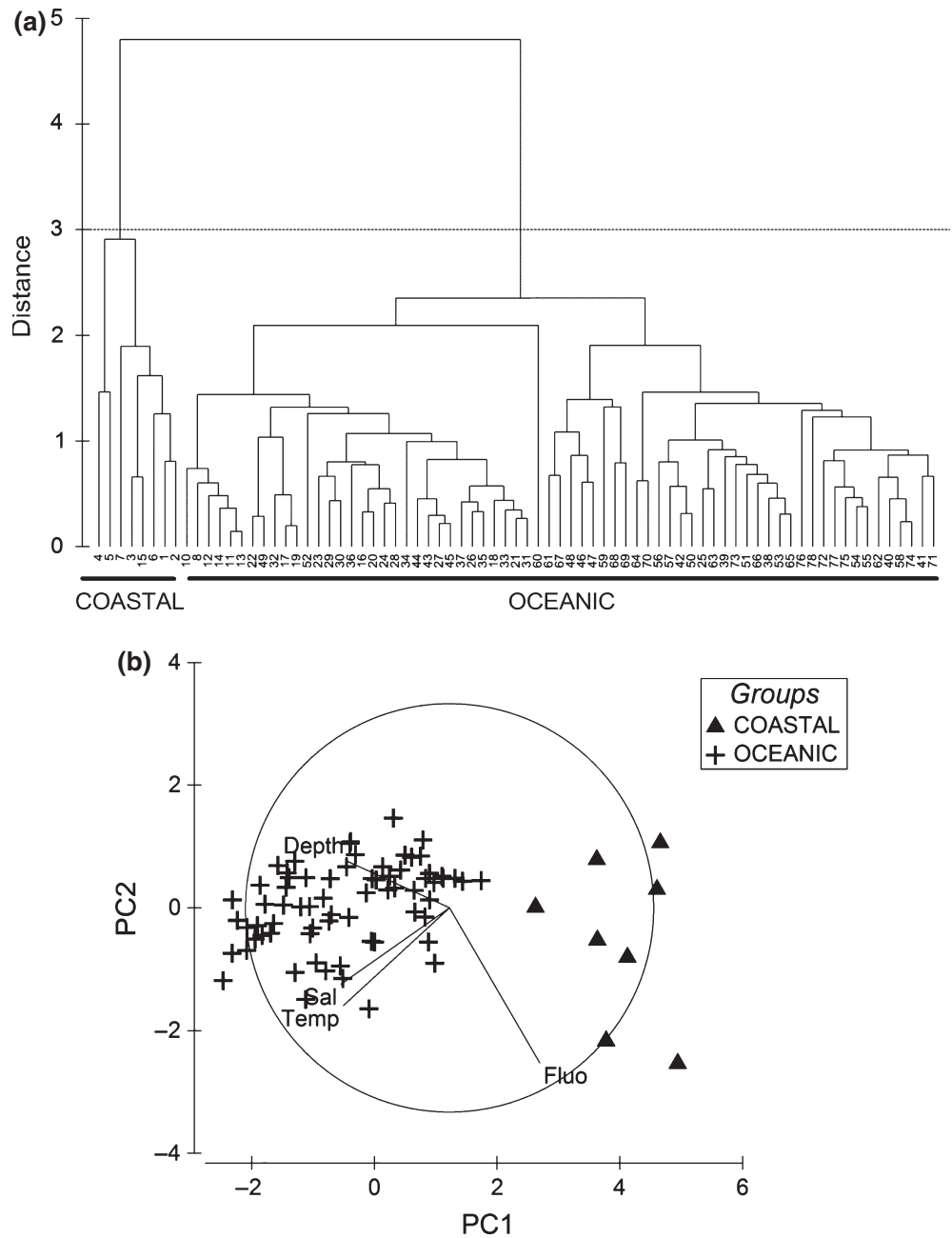

Figure 3. Clustering and ordination of sampling stations using environmental variables. (a) Hierarchical cluster from the environmental data matrix averaged across stations. (b) Principal component analysis (PCA) ordination for all stations displaying the vectors for the environmental variables analyzed. Temp, temperature at $10 \mathrm{~m}$; Sal, salinity at $10 \mathrm{~m}$; Fluo, average fluorescence; Depth, bottom depth.
Table 1. Eigenvectors for the two principal components (PC) axes derived from the principal component analysis (PCA) on the four environmental variables assessed in the study.

\begin{tabular}{lrr}
\hline Variable & \multicolumn{1}{c}{ PC1 } & \multicolumn{1}{c}{ PC2 } \\
\hline Bottom depth & -0.517 & -0.082 \\
Temperature $(10 \mathrm{~m})$ & -0.521 & 0.466 \\
Salinity $(10 \mathrm{~m})$ & -0.530 & 0.288 \\
Fluorescence (average) & 0.424 & 0.833 \\
\hline
\end{tabular}

abundant species were Maurolicus muelleri (silvery lightfish, 6.7\% TLC), Cyclothone braueri (5.9\% TLC) and Vinciguerria poweriae (5.5\% TLC). Vinciguerria was the most abundant genus (19.8\% TLC), but due to their small size or damaged state, most larvae $(12.5 \%$ TLC) could not be identified to species level. Trachurus spp. (horse mackerel, 5.0\% TLC), S. pilchardus (sardine, 4.8\% TLC) and E. encrasicolus (anchovy, $3.4 \%$ TLC) were also relatively abundant.

\section{Horizontal distribution of fish eggs and larvae}

Total larval abundances ranged between 46.12 and 1272.72 ind $\left(10 \mathrm{~m}^{2}\right)^{-1}$. Neritic larvae (mainly sardine, anchovy and horse mackerel) were retained in the coastal upwelling area (Fig. 4). The abundance of neritic larvae was higher close to shore and to the A1 eddy (Fig. 4a). Only a few neritic larvae were collected outside of the upwelling area. These larvae (Sardinella aurita, Symphodus sp. and Gobidae) were found in an area SE of Fuerteventura (stations 59-62, 69 ) influenced by the extension of the warm lee of the island, as observed by remote sensing (SeaWiFS image from 23 March 2006, not shown). Conversely, oceanic larvae were distributed throughout the study area without any clear pattern (Fig. 4b). Some aggregations were found in the vicinity of the quasi-permanent cyclonic eddy (C1) and also in the offshore southern boundary of the front.

Sardine and anchovy eggs were mainly collected close to the African coast, the latter being more 
Table 2. List of the larval fish taxa collected in the 78 sampling stations and their relative abundance (RA,\%).

\begin{tabular}{|c|c|}
\hline & RA (\%) \\
\hline \multicolumn{2}{|l|}{ ORD. ANGUILIFORMES } \\
\hline Unidentified spp. & 0.031 \\
\hline \multicolumn{2}{|l|}{ FAM.CLUPEIDAE } \\
\hline Sardina pilchardus (Walbaum, 1972) & 4.834 \\
\hline Sardinella aurita (Valenciennes, 1847) & 0.092 \\
\hline Unidentified spp. & 0.954 \\
\hline \multicolumn{2}{|l|}{ FAM.ENGRAULIDAE } \\
\hline Engraulis encrasicolus (Linnaeus, 1758) & 3.387 \\
\hline \multicolumn{2}{|l|}{ FAM.BATHYLAGIDAE } \\
\hline Bathylagidae sp1 & 0.185 \\
\hline \multicolumn{2}{|l|}{ FAM.GONOSTOMATIDAE } \\
\hline Cyclothone acclinidens (Garman, 1899) & 0.031 \\
\hline Cyclothone braueri (Jespersen \& Tåning, 1926) & 5.942 \\
\hline Cyclothone pallida (Mukhacheva, 1964) & 0.062 \\
\hline Cyclothone spp. & 0.123 \\
\hline Gonostoma denudatum (Rafinesque, 1810) & 0.647 \\
\hline Gonostoma atlanticus (Norman, 1930) & 0.369 \\
\hline Gonostoma spp. & 1.632 \\
\hline $\begin{array}{l}\text { Margrethia obtusirostre (Jespersen \& Tåning, } \\
\text { 1919) }\end{array}$ & 0.062 \\
\hline Unidentified spp. & 0.400 \\
\hline \multicolumn{2}{|l|}{ FAM.STERNOPTYCHIDAE } \\
\hline Argyropelecus hemigymnus (Cocco,1829) & 1.570 \\
\hline Maurolicus muelleri (Gmelin, 1789) & 6.712 \\
\hline Sternoptyx diaphana (Hermann, 1781) & 0.277 \\
\hline Unidentified spp. & 0.123 \\
\hline \multicolumn{2}{|l|}{ FAM.STOMIIDAE } \\
\hline Unidentified spp. & 0.462 \\
\hline \multicolumn{2}{|l|}{ FAM. PHOSICHTHYIDAE } \\
\hline Vinciguerria attenuata (Cocco, 1938) & 0.031 \\
\hline Vinciguerria nimbaria (Jordan \& Williams, 1896) & 1.817 \\
\hline Vinciguerria poweriae (Cocco, 1938) & 5.511 \\
\hline Vinciguerria spp. & 12.500 \\
\hline Yarella blackfordii (Goode \& Bean, 1896) & 0.062 \\
\hline \multicolumn{2}{|l|}{ FAM.SYNODONTIDAE } \\
\hline Synodontidae sp.B & 0.031 \\
\hline \multicolumn{2}{|l|}{ FAM.MYCTOPHIDAE } \\
\hline Benthosema suborbitale (Gilbert, 1913) & 0.493 \\
\hline Ceratoscopelus maderensis (Lowe, 1839) & 0.954 \\
\hline Ceratoscopelus warmingii (Lütken,1892) & 0.369 \\
\hline Diaphus rafinesquii (Cocco, 1838) & 0.031 \\
\hline Diaphus spp. & 1.786 \\
\hline Diogenichthys atlanticus (Tåning, 1918) & 3.510 \\
\hline Gonichthys cocco (Cocco, 1829) & 0.062 \\
\hline Hygophum benoiti (Cocco, 1838) & 0.277 \\
\hline Hygophum hygomii (Lütken, 1892) & 0.185 \\
\hline Hygophum reinhardtii (Lütken, 1892) & 0.462 \\
\hline Hygophum taaningi (Becker, 1965) & 0.031 \\
\hline Hygophum spp. & 0.031 \\
\hline Lampadena urophaos (Maul, 1969) & 0.062 \\
\hline Lampadena spp. & 0.431 \\
\hline
\end{tabular}

Table 2. (Continued)

\begin{tabular}{|c|c|}
\hline & RA (\%) \\
\hline Lampanyctus pusillus (Johnson, 1890) & 0.062 \\
\hline Lampanyctus spp. & 3.756 \\
\hline Lobianchia dofleini(Zugmayer, 1911) & 0.062 \\
\hline Lobianchia gemellarii (Cocco, 1938) & 0.616 \\
\hline Lobianchia spp. & 0.339 \\
\hline Myctophum affine (Lütken, 1892) & 0.092 \\
\hline Myctophum nitidulum (Garman, 1899) & 0.185 \\
\hline Myctophum punctatum (Rafinesque, 1810) & 1.232 \\
\hline Myctophum selenops (Tåning, 1928) & 0.031 \\
\hline Notolychnus valdiviae (Brauer, 1904) & 0.031 \\
\hline Notoscopelus resplendens (Richardson, 1845) & 0.185 \\
\hline Notoscopelus spp. & 1.632 \\
\hline Symbolophorus spp. & 0.339 \\
\hline Myctophidae spA & 0.400 \\
\hline Myctophidae spB & 0.031 \\
\hline Unidentified spp. & 3.079 \\
\hline \multicolumn{2}{|l|}{ FAM.NOTOSUDIDAE } \\
\hline Scopelosaurus lepidus (Krefft \& Maul, 1955) & 0.031 \\
\hline \multicolumn{2}{|l|}{ FAM.PARALEPIDAE } \\
\hline Paralepis coregonoides (Risso, 1820) & 0.092 \\
\hline \multicolumn{2}{|l|}{ FAM.CENTRISCIDAE } \\
\hline Macroramphosus scolopax (Linnaeus, 1758) & 0.062 \\
\hline \multicolumn{2}{|l|}{ FAM.CAPROIDAE } \\
\hline Capros aper (Linnaeus, 1758) & 0.031 \\
\hline \multicolumn{2}{|l|}{ FAM.SERRANIDAE } \\
\hline Unidentified spp. & 0.031 \\
\hline \multicolumn{2}{|l|}{ FAM.CARANGIDAE } \\
\hline Trachurus spp. & 4.988 \\
\hline \multicolumn{2}{|l|}{ FAM.MULLIDAE } \\
\hline Mullus barbatus (Linnaeus, 1758) & 0.031 \\
\hline \multicolumn{2}{|l|}{ FAM.SPARIDAE } \\
\hline Boops boops (Linnaeus, 1758) & 0.123 \\
\hline Diplodus spp. & 0.092 \\
\hline ?Pagellus acarne (Risso, 1826) & 0.308 \\
\hline Pagellus bogaraveo (Brünnich, 1768) & 0.185 \\
\hline Unidentified spp. & 0.123 \\
\hline \multicolumn{2}{|l|}{ FAM.LABRIDAE } \\
\hline Symphodus spp. & 0.031 \\
\hline \multicolumn{2}{|l|}{ FAM.GEMPYLIDAE } \\
\hline Diplospinus multistriatus (Maul, 1948) & 0.031 \\
\hline Ruvettus pretiosus (Cocco, 1833) & 0.092 \\
\hline Unidentified spp. & 0.031 \\
\hline \multicolumn{2}{|l|}{ FAM.SCOMBRIDAE } \\
\hline Scomber colias (Houttuyn, 1792) & 0.493 \\
\hline \multicolumn{2}{|l|}{ FAM.SCOPELARCHIDAE } \\
\hline Scopelarchus analis (Brauer, 1902) & 0.062 \\
\hline Scopelarchus guentheri (Alcock, 1896) & 0.031 \\
\hline Unidentified spp. & 0.400 \\
\hline \multicolumn{2}{|l|}{ FAM.GOBIESOCIDAE } \\
\hline Unidentified spp. & 0.031 \\
\hline \multicolumn{2}{|l|}{ FAM.BLENNIDAE } \\
\hline Unidentified spp. & 0.062 \\
\hline
\end{tabular}


Table 2. (Continued)

\begin{tabular}{ll}
\hline & RA (\%) \\
\hline FAM.GOBIIDAE & \\
$\quad$ Unidentified spp. & 0.954 \\
FAM.CALLYONIMIDAE & \\
$\quad$ Callyonimus spp. & 0.031 \\
FAM.OPHIDIDAE & \\
$\quad$ Unidentified spp. & 0.031 \\
FAM.TETRAGONURIDAE & \\
$\quad$ Tetragonurus atlanticus (Lowe, 1839) & 0.031 \\
FAM.SCORPAENIDAE & \\
$\quad$ Unidentified spp. & 0.031 \\
FAM.BOTHIDAE & 0.031 \\
$\quad$ Arnoglossus imperialis (Rafinesque, 1810) & 0.031 \\
$\quad$ Arnoglossus thori (Kyle, 1913) & \\
FAM.SOLEIDAE & 0.800 \\
$\quad$ Microchirus azevia (de Brito Capello, 1861) & 0.554 \\
$\quad$ Microchirus ocellatus (Linnaeus, 1758) &
\end{tabular}

abundant (Fig. 5a,b). Sardine eggs prevailed in the south of the sampling area (Fig. 5a), whereas anchovy eggs were found both south and north of the area (Fig. 5b). It is worth mentioning that some sardine eggs were found more than $60 \mathrm{~km}$ offshore (station 23). Sardine larvae also showed higher abundances in the southern stations (Fig. 5c), whereas anchovy was less abundant but more homogeneously distributed in the upwelling area. Horse mackerel larvae were also found close to shore, showing a similar distribution to sardine, except for a few larvae advected offshore within the northern filament, F2 (Fig. 5e).

Most silvery lightfish larvae were found on the slope, bounded by the offshore limit of the upwelling front, except for a few specimens found in the oceanic realm (Fig. 5f). The other abundant oceanic species were widely spread (distribution is not shown). For example, C. braueri was collected in 54 of 78 stations, $V$. poweriae in 44 , and Vinciguerria spp. in 67.

\section{Vertical distribution and diel vertical migrations}

Fish larvae were primarily collected above $105 \mathrm{~m}$ depth (Fig. 6a). More than $65 \%$ of the neritic larvae were located in the upper $35 \mathrm{~m}$ of the water column, whereas maximum densities of oceanic larvae occurred in the 80-105 m depth range. Sardine and anchovy eggs showed a shallow distribution. The bulk of sardine eggs $(98.3 \%)$ were found in the upper $50 \mathrm{~m}$, whereas most of anchovy eggs $(82.4 \%)$ were found in the surface $20 \mathrm{~m}$. As for the eggs, anchovy larvae were also collected in surface waters $(74.5 \%$ collected above $35 \mathrm{~m}$ ), whereas sardine larvae were distributed slightly deeper $(64.3 \%$ above $50 \mathrm{~m})$ (Fig. 6b,c). Horse mackerel larvae were also found in surface waters but showed a wider vertical distribution (Fig. 6d). As for oceanic larvae, silvery lightfish were distributed in a wide depth range (Fig. 6e): $75.2 \%$ of these larvae were found between 50 and $150 \mathrm{~m}$ depth. Cyclothone braueri was concentrated in the upper $80 \mathrm{~m}$ (Fig. 6f), whereas Lampanyctus spp. showed higher concentrations in the 35-100 m depth range. Vinciguerria poweriae and Diogenichthys atlanticus showed deeper distributions (76.2 and $75.9 \%$ of their larvae found between 55 and $130 \mathrm{~m}$ depth).

Vertical distributions were also influenced by mesoscale activity. Most of the sardine and anchovy eggs and larvae were collected in shallow coastal waters, but some were occasionally collected below $100 \mathrm{~m}$ (e.g., anchovy eggs in the zonal transect 3; sardine larvae in the zonal transect 7; Figs 1 and 7). This wider depth distribution was found in the vicinity of the anticyclonic eddy centered in station 13 on the northern transect and the A1 eddy (centered in station 25) in the south. Other species, e.g., horse mackerel (A1-eddy) and silvery lightfish (station 13-eddy), were deepened by these anticyclonic eddies (Fig. 7).

Diel vertical migrations of the most abundant taxa, those with $>100$ individuals collected, were analyzed (Fig. 6, Table 3). The larval fish assemblage performed a significant DVM type I (Student's t-test, $P<0.01$ ) (Fig. 6a). Among the studied taxa, only horse mackerel larvae showed significant DVM type II (Student's $t$-test, $P<0.01$ ), with a displacement range of $33 \mathrm{~m}$. Larval abundances were higher at night than during daylight for most species, suggesting net avoidance.

\section{Larval fish assemblages}

Hierarchical clustering identified two larval fish assemblages (coastal and oceanic) at a similarity level of 23\% (Fig. 8a). Five stations (46, 47, 52, 70, 75) were considered outliers. The 2D-MDS ordination confirmed the results of the cluster analysis (Fig. 8b). Although the MDS stress was relatively high $(<0.18)$, a $2 \mathrm{D}$ ordination approach was adopted because stress levels $(<0.18)$ are considered sufficiently low when the combination of clustering and ordination analysis is used (Clarke, 1993). SIMPER routine identified taxa typifying both larval assemblages (Table 4). Sardina pilchardus, Trachurus spp. and E. encrasicolus contributed $>70 \%$ of the average similarity within the coastal assemblage, and Vinciguerria spp. represented $\sim 50 \%$ of the average similarity within the oceanic assemblage. The Bray-Curtis dissimilarity between 
Figure 4. SeaWiFS satellite images from 7 April 2006 showing the horizontal distribution of sea-surface chlorophyll concentration in the study area. Superimposed is displayed the horizontal distribution of (a) total neritic larvae (ind $10 \mathrm{~m}^{-2}$ ) and (b) total oceanic larvae (ind.10 $\mathrm{m}^{-2}$ ). The offshore boundary of the upwelling front $\left(17.4^{\circ} \mathrm{C}\right.$ isotherm at $110 \mathrm{~m}$ ) is displayed as a black line.

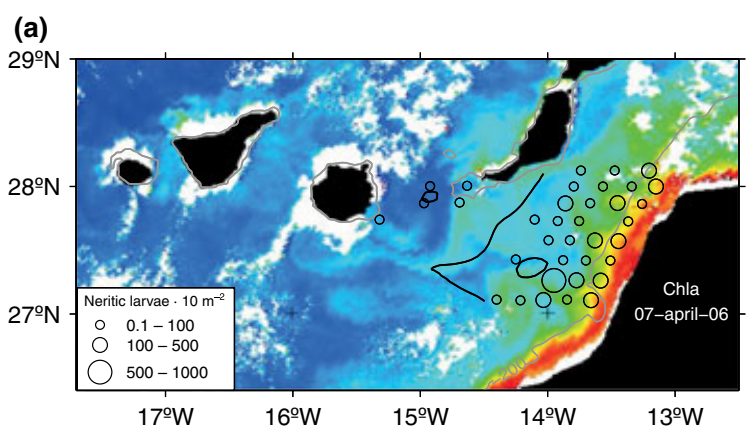

(b)

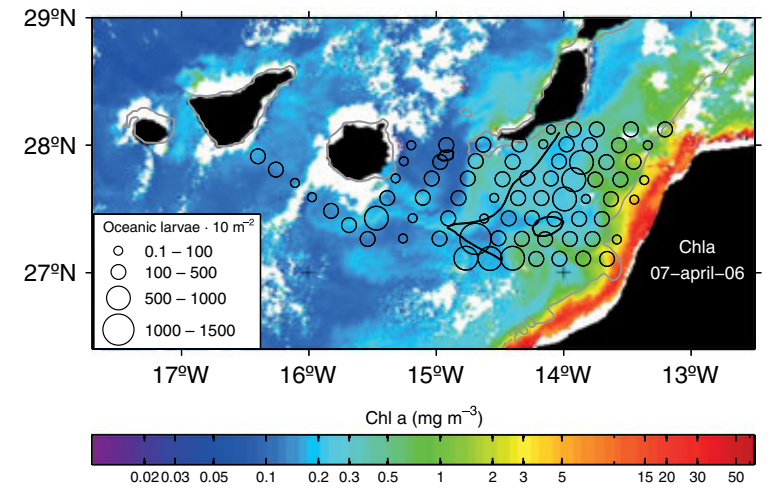

the coastal and the oceanic assemblages indicated the best discriminators between both groups (Diss/SD $>1$ ): Sardina (S. pilchardus), Trachurus, Vinciguerria, Lampanyctus spp. and Diogenichthys (D. atlanticus). The former two genera characterized the coastal assemblage, whereas the other three were only present in the oceanic assemblage. There were similar concentrations of Maurolicus muelleri in both assemblages (Table 4) due to its distribution on the shelf break (Fig. 5f).

Cluster analysis, at a similarity level of $20 \%$, and MDS ordination identified two genus assemblages (Fig. 9). Genera previously identified in the SIMPER routine characterizing the station assemblages were also grouped into coastal and oceanic taxa assemblages (Table 4). The coastal assemblage was composed of E. encrasicolus, S. pilchardus, Trachurus spp. and Microchirus spp. On the other hand, the oceanic assemblage was split into two subgroups at a similarity level of $25 \%$. The first included those genera only found in oceanic waters (e.g., Notoscopelus, Ceratoscopelus,
Gonostoma); the second, those genera relatively abundant and also present in coastal waters (Vinciguerria, Cyclothone and Maurolicus).

As for the vertical structure of the larval fish community, groups formed by cluster analysis (not shown) were not ecologically interpretable. Therefore, no further analyses of this group were carried out.

Finally, the Bio-Env routine showed that the environmental factor that best explained the variability of the horizontal distribution of larval fish genera was fluorescence $(\rho=0.357)$, followed by bottom depth $(\rho=0.353)$, salinity $(\rho=0.303)$ and temperature $(\rho=0.254)$. The combination of these variables led to depth and fluorescence together explaining $42.2 \%$ of the variability. When depth was excluded from the analysis, a combination of fluorescence and temperature returned the best results $(\rho=0.391)$. These results match those of the larval assemblages, being the coastal larval assemblage found in the very productive coastal waters (high fluorescence, shallow waters, low salinity, low temperature), whereas the oceanic assemblage is present in the less productive oceanic waters (low fluorescence, deeper waters, high salinity, high temperature).

\section{DISCUSSION}

The present study constitutes the first analysis of the entire larval fish community in the Canaries-African CTZ during the weak upwelling season. The relatively high spatial resolution of the sampling grid allowed a good description of the larval fish community in the area and how it is influenced by the local hydrography. During this sampling, three well-defined hydrographic regions were identified: upwelling, front and open ocean. Related to these regions, we observed an onshore-offshore transition in the larval fish community structure, from a coastal assemblage dominated by small pelagics (sardine, anchovy, mackerel), bounded by the upwelling front, to an offshore assemblage dominated by mesopelagic species (myctophids, photichtids and gonostomatids). This transition is a common pattern in EBUS (e.g., Richardson and Pearcy, 1977; Rojas et al., 2002; Auth and Brodeur, 2006). Several mesoscale hydrographic features were detected in the area during the present study (i.e., eddies, filaments). These structures influenced the horizontal and vertical distribution of both the neritic and the oceanic fish larvae.

\section{The coastal assemblage}

The coastal larval fish assemblage occurred in the shallow and productive waters of the NW African coast, 
Figure 5. Horizontal distribution of abundances (no. $10 \mathrm{~m}^{-2}$ ) of (a) Sardina pilchardus eggs; (b) Engraulis encrasicolus eggs; (c) Sardina pilchardus larvae; (d) Engraulis encrasicolus larvae; (e) Trachurus spp. larvae; and (f) Maurolicus muelleri larvae. The offshore limit of the upwelling front is displayed as a black line.

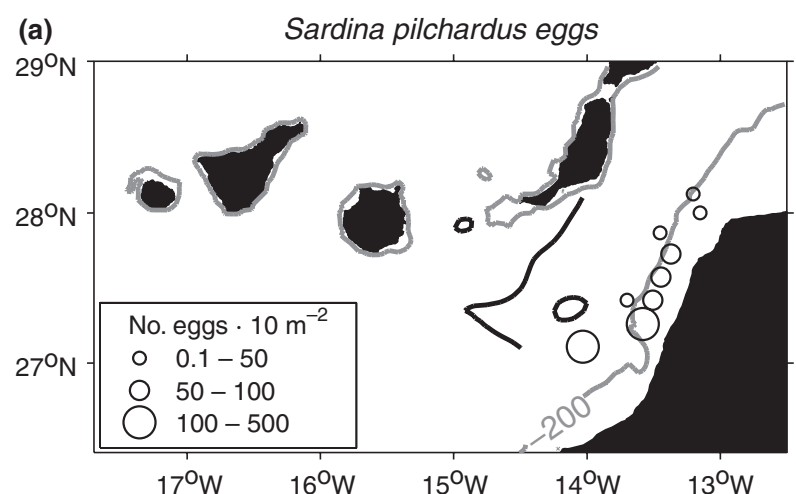

(c)
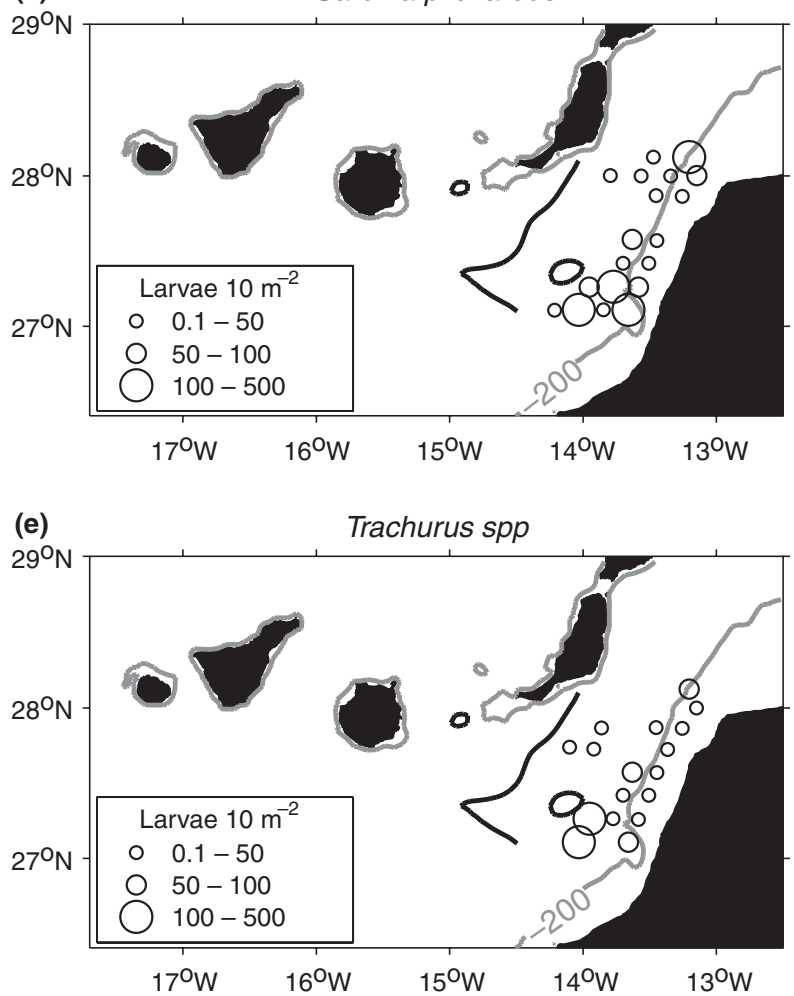

and on the shelf break-slope regions. Four genera (sardine, anchovy, horse mackerel and sole) were the most abundant within this group. In this system, sardine and anchovy spawn year around, but winter is the main spawning season for sardine and summer for anchovy (Berraho, 2007). During our sampling, the spawning peak of sardine was apparently ending (number of eggs < number of larvae), whereas anchovy spawning seemed to be increasing (number of eggs $>$ number of larvae). Abundances of egg and larvae of both species were comparable to those found in

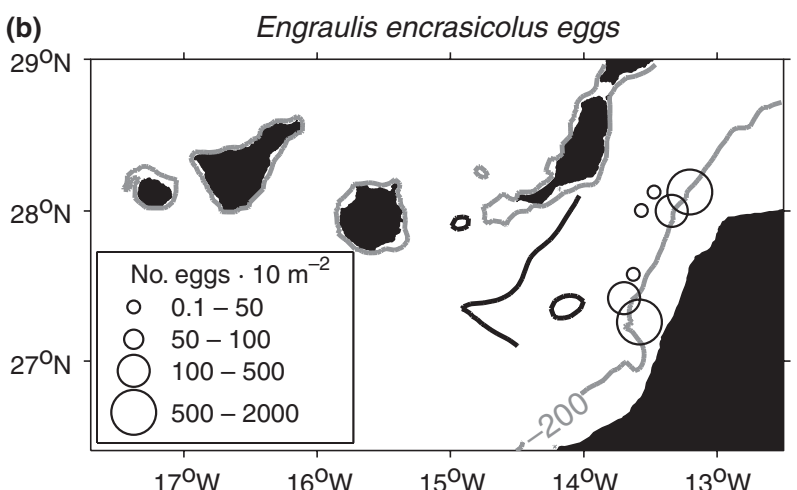

(d)
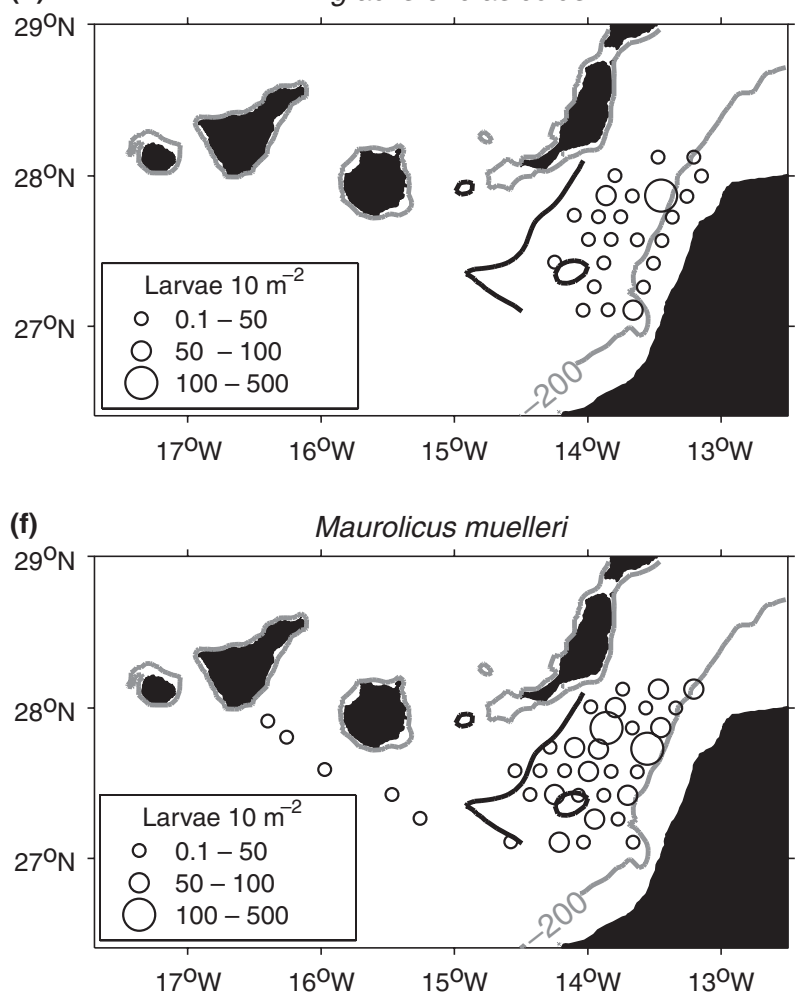

other studies done in spring in the upwelling region (Ettahiri, 1996; Ettahiri et al., 2003; Berraho, 2007). Larvae were distributed further offshore than eggs, but never off the frontal area. In terms of vertical distribution, anchovy and sardine eggs and larvae showed a similar surface distribution in the water column to that reported for clupeids worldwide (Boehlert et al., 1985; John, 1985; Olivar et al., 2001; Coombs et al., 2004). Anchovy spawning seems to occur in shallower water than spawning of sardine (Olivar et al., 2001; Coombs et al., 2004). 
Figure 6. Vertical distribution of the mean day (white bars) and night (dark bars) larval concentrations (ind $1000 \mathrm{~m}^{-3}$ ) of (a) total larvae; (b) Sardina pilchardus; (c) Engraulis encrasicolus; (d) Trachurus spp.; (e) Maurolicus muelleri; (f) Cyclothone braueri larvae.

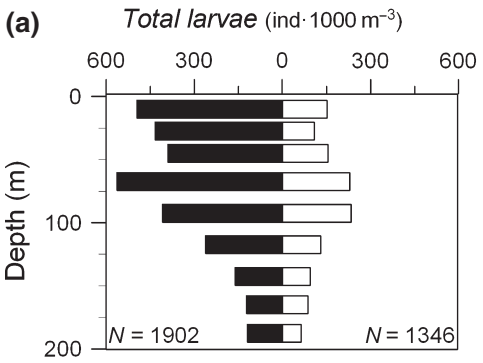

(c) Engraulis encrasicolus (ind $1000 \mathrm{~m}^{-3}$ )

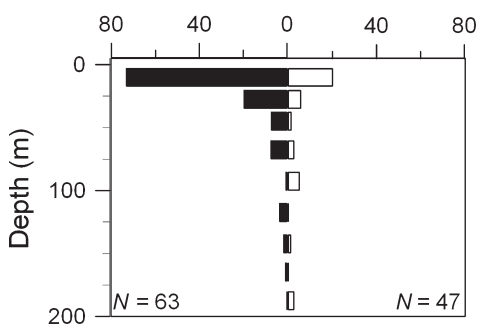

(e) Maurolicus muelleri (ind $\cdot 1000 \mathrm{~m}^{-3}$ )

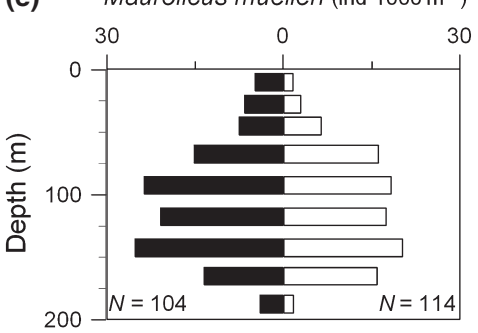

(b) Sardina pilchardus (ind $1000 \mathrm{~m}^{-3}$ )
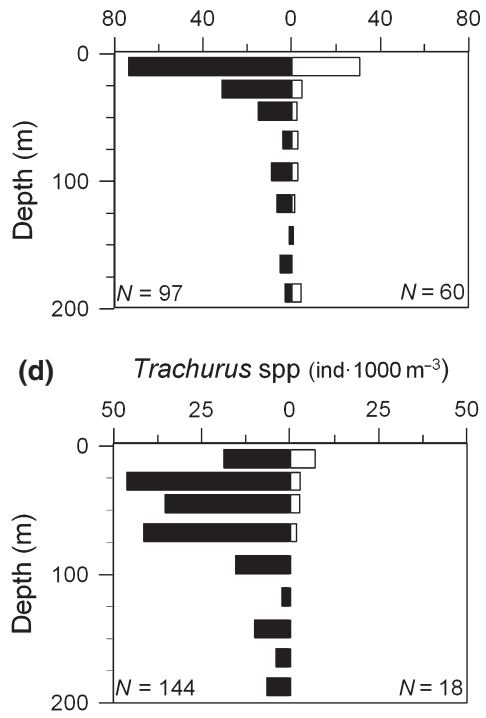

(f) Cyclothone braueri (ind $1000 \mathrm{~m}^{-3}$ )

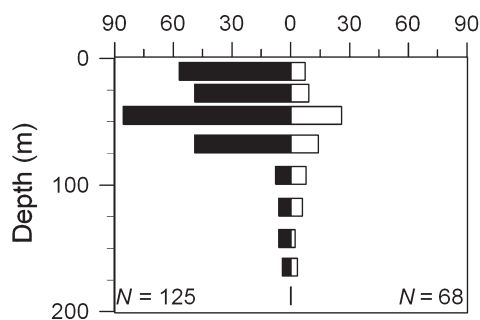

Horse mackerel larvae were unfortunately not identified to species level in this study. However, these larvae were probably Trachurus trachurus and Trachurus picturatus, which reproduce during winter in the African upwelling region (Berraho, 2007). Horse mackerel larvae were mainly collected in the upper $100 \mathrm{~m}$, slightly deeper than previously reported for $T$. trachurus in the NE Atlantic (Coombs et al., 2001; Rodríguez et al., 2011). Those authors stated that their range can widen in the absence of a thermocline. In our study, anticyclonic eddies have likely deepened the larvae in the vicinity of the eddy core (e.g., eddy A1).

Two species of the only Soleidae genus collected in this study (Microchirus spp.) inhabit our study area (Microchirus azevia and Microchirus ocellatus). Their spawning periods are not well-known in the area, but Palomera and Rubies (1982) described the presence of larvae from both species (also in spring) off the Saharan shelf. The spawning period of M. azevia off Portugal peaks in January-May (Afonso-Dias et al., 2005), suggesting that they also likely reproduce in winter in the NW African upwelling region. On the other hand, Rodríguez et al. (1999) found M. ocellatus larvae in summer. Further studies will be necessary to determine the spawning season of these species in the area.

All the species included in this coastal assemblage were collected in the upwelling area, bounded by the dynamic height contour of $62.5 \mathrm{~cm}$. Dynamic height has been recently proposed as a good proxy to estimate spawning habitats for small pelagics in the California upwelling system (Asch and Checkley, 2013). This variable combines measurements of temperature, salinity and geostrophic velocity, resulting in a useful predictor in highly dynamic scenarios (Lindo-Atichati et al., 2012). Nevertheless, no differences in the distribution of sardine and anchovy eggs (both occurring at dynamic heights of 59.5-61 cm) were observed in our study. Further analyses would be necessary to assess the predictor power of this variable to shape spawning preferences in this area of the Canary EBUS, including past sampling on the area during the spawning peak for both species.

The oceanic assemblage

Abundances of oceanic fish larvae recorded in this study were higher than those registered in previous samplings carried out in the area (Rodríguez et al., 
Figure 7. Vertical distribution of Sardina pilchardus and Engraulis encrasicolus eggs and larvae, and Maurolicus muelleri larvae across three zonal transects: ZT3 $\left(27.8^{\circ} \mathrm{N}\right)$, ZT7 $\left(27.25^{\circ} \mathrm{N}\right)$ and ZT8 $\left(27.1^{\circ} \mathrm{N}\right)$. Units: ind $/\left(1000 \mathrm{~m}^{3}\right)$.

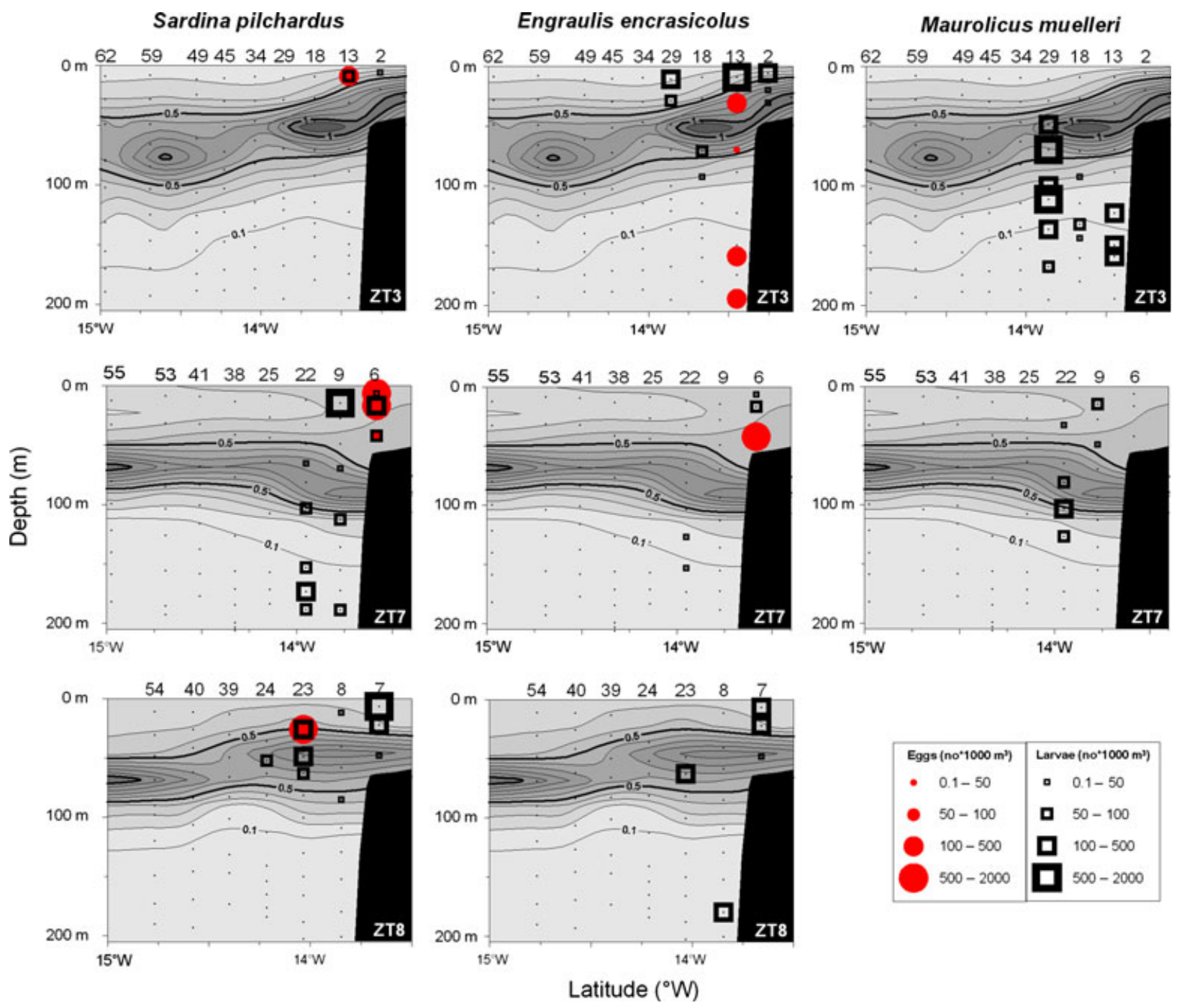

1999; Rodríguez et al., 2004). These higher abundances may be related to the absence of a giant upwelling filament displacing oceanic larvae further offshore. The oceanic assemblage was dominated by the circumglobal species: Vinciguerria poweriae, Cyclothone braueri, Maurolicus muelleri and Diogenichthys atlanticus. These species are also common in oceanic assemblages in other EBUS (Moser and Smith, 1993; Rojas et al., 2002). Vinciguerria poweriae and C. braueri likely reproduce during the entire year in relatively low latitudes (Jespersen and Taning, 1926; McKelvie, 1989) and certainly contribute to the winter-spring larval assemblage off the Canary Islands (Rodríguez et al., 2009; Moyano and Hernández-León, 2011). In addition, the vertical distribution of oceanic species is consistent with previous observations in the region
(Rodríguez et al., 2006) and in the Mediterranean Sea (Masó and Palomera, 1984; Olivar et al., 2010).

Larvae of silvery lightfish were mainly found on the shelf break and the slope regions, bounded by the upwelling front. This distribution is in agreement with previous findings from the Benguela upwelling region that identified this species as a shelf resident species, spawning mainly on the shelf break (Armstrong and Prosch, 1991; Olivar et al., 1992). Other studies state that this species can be very abundant in slope areas (Gjosaeter and Kawaguchi, 1980). Ontogenetic vertical migrations have been observed in this species: recently hatched larvae are found in the $100-400 \mathrm{~m}$ depth range, ascending to the upper $100 \mathrm{~m}$ during the preflexion stage and finally descending again to deeper layers as they grow (John and Kloppmann, 
Table 3. Daytime weighted mean depth distribution (DWDM) and amplitude of diel vertical migration (DVM, $\mathrm{m}$ ) of total fish larvae and that of the most abundant larval fish species. Negative values of DVM indicate reverse vertical migration (deeper at night).

\begin{tabular}{lcc}
\hline & DWDM & DVM \\
\hline Total larvae & 82.67 & $12.85^{*}$ \\
Sardina pilchardus & 40.22 & 2.88 \\
Engraulis encrasicolus & 42.92 & 17.28 \\
Trachurus spp. & 26.48 & $-33.55^{*}$ \\
Maurolicus muelleri & 109.84 & 4.27 \\
Cyclothone braueri & 61.91 & 16.53 \\
Diogenichthys atlanticus & 85.32 & -1.26 \\
Lampanyctus spp. & 77.74 & 9.64 \\
Vinciguerria poweriae & 104.41 & 8.86 \\
\hline
\end{tabular}

*Significant DVM (Student's t-test, $P<0.01$ ).

1989). Those results will support the wide vertical distribution observed in the present study $(50-200 \mathrm{~m})$; unfortunately, ontogenetic migrations could not be tested due to the absence of larval sizes.

Other species that appeared in lower abundances at oceanic stations (e.g., Lobianchia dofleini, Lobianchia gemellarii, Myctophum nitidulum, Argyropelecus hemigymnus) are only present in the Canary waters in winter-spring (Moyano and Hernández-León, 2011). Nevertheless, they likely spawn year-round in the open ocean, since their larvae have been also found in summer in the area (Rodríguez et al., 1999; Rodriguez et al., 2004). Additional genera contributing to the oceanic larval assemblage were Lampanyctus and Gonostoma. These genera include circumglobal species inhabiting the mesopelagic domain, whose larvae are common in the Canary waters year-round (Moyano and Hernández-León, 2011).

\section{Diel vertical migrations}

DVMs of fish larvae are relatively well-documented (Boehlert et al., 1985; Neilson and Perry, 1990; Auth et al., 2007). Several hypotheses have been proposed to explain these migrations (e.g., predator avoidance, feeding, search of optimal light conditions). The intraspecific variability for each developmental stage also highlights the importance of understanding ontogenetic migrations (Norcross and Shaw, 1984; Olivar et al., 2001). However, in this study two main factors precluded DVM analysis in depth: (i) the net and

Figure 8. (a) Hierarchical clustering and (b) non-metric multidimensional scaling (MDS) ordination of the sampling stations based on the Bray-Curtis similarity matrix of larval fish genus abundance averaged across stations.

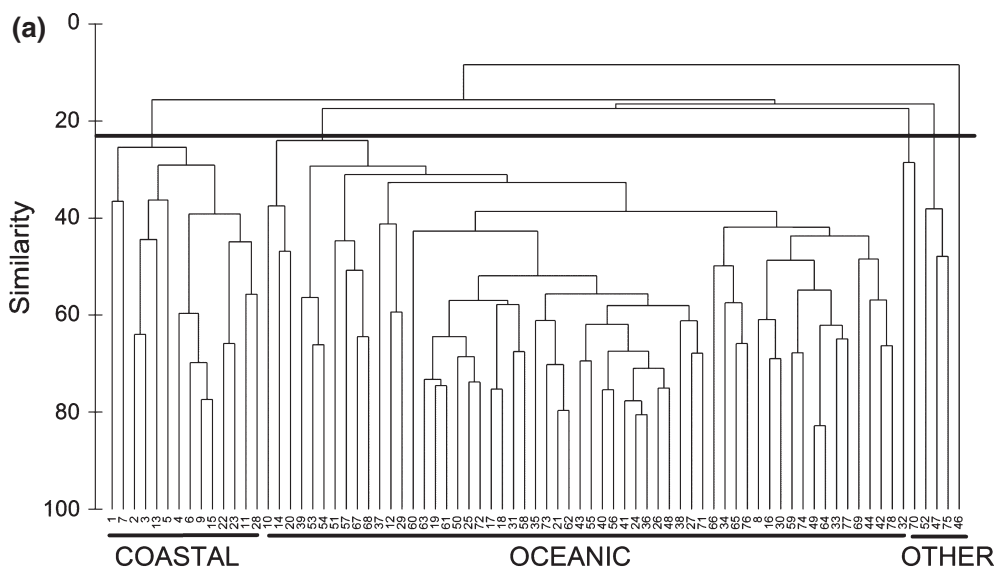

(b) 
Table 4. Similarity percentage (SIMPER) results for the two larval fish assemblages identified in Fig. 8 (coastal and oceanic). The most important genera contributing to the average similarity within each group (percentage of contribution, \%) are shown. For single-species genera (within this study), the species name is indicated in parentheses. The ratio of the contribution of each species to the average dissimilarity between both groups to the standard deviation (Diss/SD) is given.

\begin{tabular}{lllr}
\hline & & & Diss/ \\
& Coastal (\%) & Oceanic (\%) & DS \\
\hline Sardina (S. pilchardus) & 25.48 & & 1.13 \\
Trachurus spp. & 25.47 & & 1.11 \\
Engraulis & 20.55 & & 0.92 \\
$\quad$ E. encrasicolus) & & & \\
Vinciguerria spp. & 11.09 & 49.49 & 1.18 \\
Maurolicus (M. muelleri) & 4.59 & 5.69 & 0.85 \\
Microchirus spp. & 3.36 & & 0.61 \\
Cyclothone spp. & & 14.19 & 0.79 \\
Lampanyctus spp. & & 9.36 & 1.18 \\
Diogenichthys & & 8.96 & 1.02 \\
$\quad$ (D. atlanticus) & & & \\
Gonostoma spp. & & 4.28 & 0.88 \\
\hline
\end{tabular}

sampling design used in our study was not ideal: LHPR is not the most desirable larval fish sampler for taxonomy because, as mentioned above, it damages the larvae (i.e., larval size not available); (ii) vertical distribution was influenced by mesoscale activity, potentially masking the real DVM. In summary, although the present study contributes to the scarce knowledge of the vertical distribution and DVM of fish larvae in the Canaries-African CTZ, results should be considered carefully.

Knowledge of the vertical migrations of fish larvae in the water column is crucial to understanding the interactions within the larval assemblage and the potential effect of oceanographic features on its horizontal structure (Stenevik et al., 2003; Fiksen et al., 2007). Anchovy larvae perform DVM Type I in the Mediterranean Sea (Olivar and Sabates, 1997; Olivar et al., 2001; Sabatés et al., 2008), similar to anchoveta larvae off the Humboldt EBUS (Landaeta and Castro, 2013). This DVM would contribute to avoid the enhanced offshore advection generated by the strong summer upwelling favorable winds. However, other studies in the Benguela EBUS (DVM Type II; Stenevik et al., 2007) and in the Canary EBUS (no DVM; our study; Rodriguez et al., 2006) failed to observe this pattern. Sardine larvae frequently perform DVM type II (Olivar et al., 2001) but, again, this was not observed in the study area (our study, Rodriguez et al., 2006). Small changes in the water column may imply large changes in the horizontal distribution of larvae and thus in terms of dispersal and retention processes (Stenevik et al., 2003; Fiksen et al., 2007). Understanding DVM and larval behavior adaptations for each particular system is therefore essential for quantifying and modeling larval transport dynamics (Brochier et al., 2008, 2011a).

\section{Influence of the upwelling front and mesoscale features on larval distribution}

Upwelling systems constitute a challenging environment for neritic fish, since they have to develop adequate spawning strategies and behavior during their early life stages to recruit successfully back the coast. Fish larvae need to overcome the negative effects of hydrographic features such as filaments or eddies, which together with offshore Ekman transport strongly affect their distribution (Parrish et al., 1981; Norcross and Shaw, 1984). Previous studies in the area have frequently registered giant upwelling filaments advecting clupeid larvae (sardine, anchovy) offshore, even reaching the eastern shores of some islands of the Canary archipelago (Rodríguez et al., 1999, 2009; Moyano et al., 2009). However, the present study recorded larval retention of African small pelagics (i.e., sardine, anchovy, horse mackerels) in the upwelling area, despite the presence of several dispersive structures (e.g., filaments). Eggs and larvae from these small pelagics were collected within the Ekman layer (20-60 m thickness in the area; Mittelstaedt, 1983), being thus susceptible to offshore advection. But due to the presence of the upwelling front acting as a natural barrier for dispersal (or absence of giant upwelling filaments) and/or of an onshore flow generated in between the C1-A1 dipole, neritic larvae were successfully retained within the upwelling area. Frontal areas are acknowledged to be a barrier for dispersal in upwelling (e.g., Bjorkstedt et al., 2002) and non-upwelling systems (e.g., Sabatés and Olivar, 1996; Galarza et al., 2009). In fact, several studies point out the possibility that larval retention in upwelling systems is more widespread than previously thought (e.g., Parrish et al., 1981; Gorbunova et al., 1986; Morgan and Fisher, 2010). These authors suggest that changes in the vertical positioning of the larvae, either daily or ontogenetically, may help them avoid offshore transport. Unfortunately, poor larval preservation precluded us from analyzing changes in vertical distribution with larval size.

The F2-C1 complex has already been proposed as a retention structure for larvae of neritic fishes in the 
Figure 9. (a) Clustering and (b) nonmetric multidimensional scaling (MDS) ordination of the genera density matrix averaged across genera.
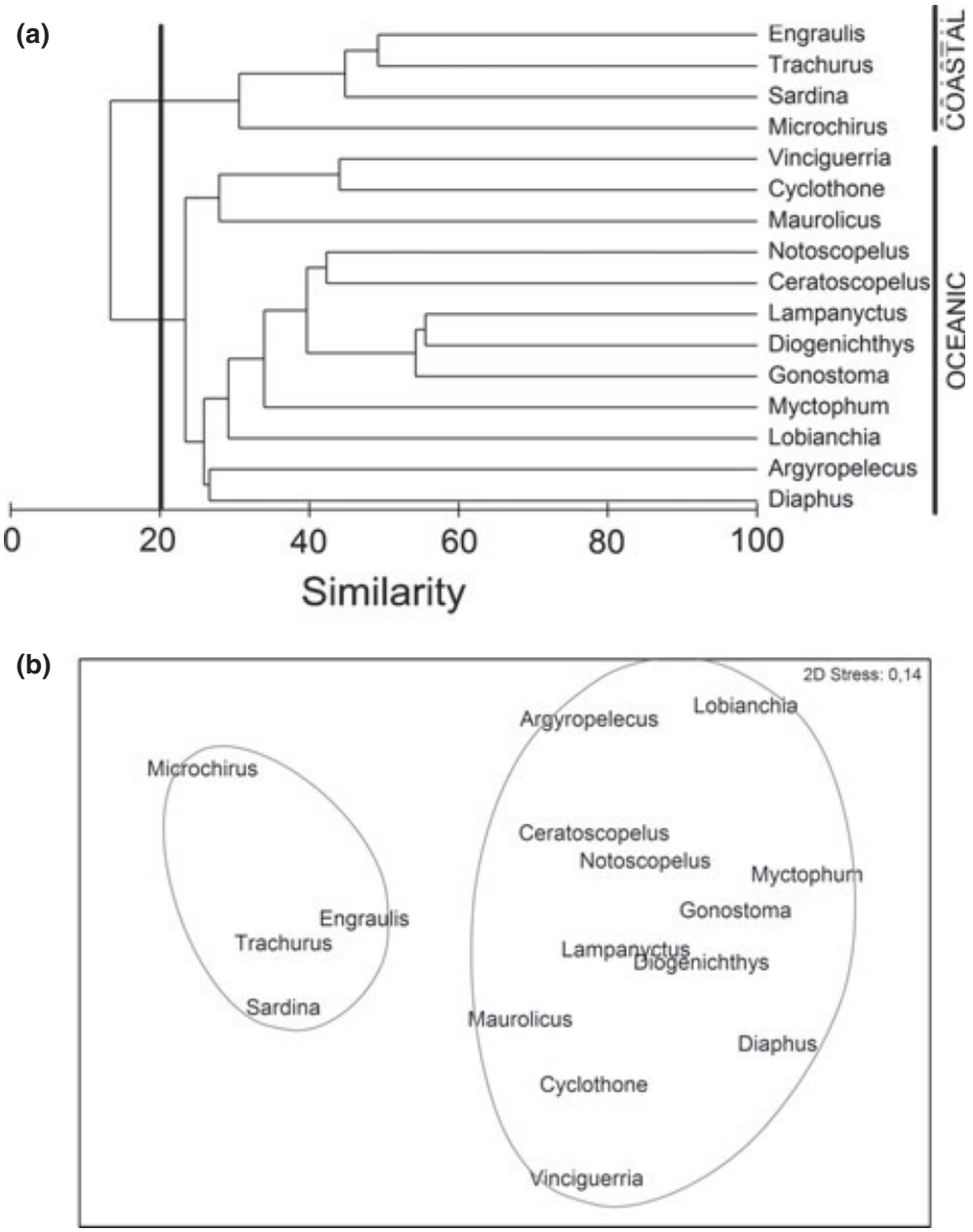

Canaries-African CTZ (Rodríguez et al., 1999). But the present study suggests that, at least outside of the strong upwelling season, the C1-A1 dipole is likely more relevant to transport neritic larvae back to coast, where they can be then recruited to the African coastal fish populations. A recent study in the California upwelling has identified the importance of this eddy-to-eddy interaction for transporting dense packets of larvae back to the coast (Harrison et al., 2013). These eddy-eddy retention mechanisms, which avoid large larval losses, seem to be common in upwelling systems. In addition to the mere retentive effect, offshore eddies can be a high food - low predation scenario, optimal for maximizing growth and survival in upwelling (Logerwell and Smith, 2001; Logerwell et al., 2001; Hutchings et al., 2002) and non-upwelling regions (Irigoien et al., 2008; Sabatés et al., 2013). Offshore advected larvae can thus benefit from a temporally sporadic favorable habitat in which they have a better chance to grow and survive before returning onshore to recruit. Cyclonic eddies seem to be a perfect example, since nutrients are pumped to surface waters enhancing phyto- and zooplankton production. Logerwell et al. (2001) argued, based on a bioenergetics model for Pacific sardine, that anticyclonic eddies also may display higher resources for fish larvae than the surrounding offshore waters. Accumulations of zooplankton in the periphery of cyclonic eddies and in the core of anticyclonic eddies has been observed on island-generated eddies in the Canaries-African CTZ (Hernández-León et al., 2007). In fact, preliminary analysis of the zooplankton from a zonal transect (T5) collected during this study found increased copepod biomass and abundance within the F2 filament and at the edges and core of A1 (Garijo et al., 2011). Unfortunately, we do not have more zooplankton data to explore these hypotheses in depth at this point.

Dispersal and retention processes in upwelling systems have been commonly assessed for commercial species, whereas mesopelagic species have often been disregarded from the picture. Oceanic species were sparsely distributed across the sampling area, but 
higher accumulations were found in the southern part of the frontal area and in the vicinity of the anticyclonic eddy (centered on station 13). The upwelling frontal area was likely acting as a concentration mechanism, providing a high food environment not only for neritic but also for oceanic larvae. In those stations close to the frontal area, there were large differences in the vertical distribution of both groups, most oceanic larvae being located in the $50-150 \mathrm{~m}$ depth range. Nevertheless, some species such as C. braueri were found in shallower layers, coexisting with neritic larvae. Although larval abundances of oceanic species may be lower than those of neritic species, both groups can potentially compete for resources, especially in the vicinity of mesoscale structures, which can alter their vertical distribution. Considering that some neritic and oceanic fish species share the same environment during their early stages, and given the trophic interactions that may exist among them, integrated monitoring tools should be given further consideration. Acknowledging the outcome of recent studies about the sensitivity of mesopelagic species to climate-driven processes (Koslow et al., 2013), now, more than ever, we should start focusing our attention on the deep-sea non-commercial species. A deeper understanding of the trophic links and interactions between the different components of the ecosystems is still needed before future integrated ecosystem-based assessment and management in large marine ecosystems, especially in the Canary EBUS, can be accomplished.

\section{Larval inputs to island populations}

Connectivity through larval stages of small pelagic fish between the NW African coast and the Canary Islands has been suggested in several studies (Bécognée et al., 2006; Moyano et al., 2009; Rodríguez et al., 2009). Nevertheless, the mechanisms (and condition) in which these larvae arrive to the islands are still unknown. A modeling study, carried out by Brochier et al. (2011a), predicted that 10 days is the minimum time that a generic clupeid larvae needs to travel from the African coastal region to Gran Canaria Island. Most of the sardine and anchovy spawning likely occurs on the African shelf, but in the present study we found some sardine eggs approximately $60 \mathrm{~km}$ offshore. This offshore sardine spawning has been reported previously for the region by Berraho (2007). If this slope spawning is taken into consideration, then the traveling time for sardine larvae to the eastern islands of the Canary archipelago will be highly reduced. These shorter travel times would then match observations of small sardine larvae $(\sim 5.5 \mathrm{~cm})$ off Gran Canaria Island in summer, outside of their winter-spring spawning season in the Canary archipelago waters (Moyano et al., 2009). Consequently, this slope spawning should be also taken into account for forthcoming modeling approaches.

Larval fish transport among islands within the Canary archipelago has never been studied. Neritic fish larvae transported offshore from Fuerteventura Island were found in the proximity of Gran Canaria Island during this study. Two main reasons allowed us to discard the African origin for these larvae: (i) S. aurita was out of their spawning season in the African coast (i.e., summer, Ettahiri et al., 2003) but not in the islands (Moyano and Hernández-León, 2011); (ii) Gobidae and Labridae are relatively abundant in the coastal region of Fuerteventura. Accumulation of larval fish within island warm wakes has already been described in the Canary Islands (Rodríguez et al., 2001; Moyano and Hernández-León, 2009; Moyano et al., 2009). Considering that Fuerteventura and Gran Canaria Islands are $\sim 50 \mathrm{~km}$ apart and the position of the Fuerteventura lee, a periodical larval transport from Fuerteventura to Gran Canaria following the direction of the Canary Current flow is very likely. Results from the present study suggest that these larval inputs between islands within the Canaries archipelago are highly possible.

Understanding and quantifying larval connectivity to and among archipelagos is vital for fisheries management (Cowen et al., 2000). Frequent and long-term monitoring of larval dynamics in the Canaries and the Canaries-African CTZ together with larval nutritional condition and genetic analysis are essential for assessing connectivity in the area. So far, no study has assessed the nutritional condition of larvae advected to the islands, so their fate in the new populations is uncertain.

\section{CONCLUSION}

The present study highlights once again the importance of understanding the effect of dispersal, enrichment and retention processes for disentangling potential recruitment scenarios in highly dynamic upwelling regions (e.g., Lett et al., 2006). In this sense, Brochier et al. (2011b) suggest that the success of small pelagics in the Humboldt upwelling region might be related to its higher retention rates compared with the other three main upwelling regions. Our data support the fact that retention in the NW African upwelling region is potentially larger than previously thought due to the retentive effect of the upwelling front combined with the C1-A1 eddy dipole. The question of whether these eddies also work as high 
food - low predation scenarios remains unresolved for this system.

Finally, our study emphasizes the lack of data in the Canary system concerning the early life stages of fish, compared with the other three main EBUS. These very dynamic regions lead to scenarios in which neritic and oceanic fish larvae coexist. Although the abundances of both groups may differ greatly, we argue that the interspecific interactions certainly deserve further attention. In addition, given the key role that mesopelagic fishes have in these environments (prey for larger fish, carbon transfer to deep ocean) and the impact of larval survival on recruitment, further (and frequent) monitoring of all stages of these species should be conducted in the future, especially in the frame of ecosystem-based assessment and management.

\section{ACKNOWLEDGEMENTS}

The authors would like to thank the colleagues from the Biological Oceanography Group and UTM technicians that participated in the CONAFRICA 0603 cruise. David Checkley and another anonymous reviewer are acknowledged for their comments on the manuscript. This study was supported by the Spanish Ministry of Education and Science through the projects CONAFRICA (Cicyt CTM2004-02319) and MAFIA (CTM2012-39587). M.M. was supported by a FPU fellowship (AP 2005-4742) from the Spanish Ministry of Science and a Postdoctoral Fellowship from the Alexander von Humboldt Foundation.

\section{REFERENCES}

Afonso-Dias, I., Reis, C., Andrade, J.P. (2005) Reproductive aspects of Microchirus azevia (Risso, 1810) (Pisces: Soleidae) from the south coast of Portugal. Sci. Mar. 69:275-283.

Arístegui, J., Barton, E.D., Álvarez-Salgado, X.A. et al. (2009) Sub-regional ecosystem variability in the Canary Current upwelling. Prog. Oceanogr. 83:33-48.

Arkhipov, A. (2009) Seasonal and interannual variation of ichthyoplankton off the coast of the Moroccan Sahara. J. Ichthyol. 49:228-235.

Armstrong, M.J. and Prosch, R.M. (1991) Abundance and distribution of the mesopelagic fish Maurolicus muelleri in the southern Benguela system. S. Afr. J. Mar. Sci. 10:13-28.

Asch, R.G. and Checkley, D.M. (2013) Dynamic height: a key variable for identifying the spawning habitat of small pelagic fishes. Deep-Sea Res I 71:79-91.

Auth, T.D. and Brodeur, R.D. (2006) Distribution and community structure of ichthyoplankton off the coast of Oregon, USA, in 2000 and 2002. Mar. Ecol. Prog. Ser. 319:199-213.

Auth, T.D., Brodeur, R.D. and Fisher, K.M. (2007) Diel variation in vertical distribution of an offshore ichthyoplankton community off the Oregon coast. Fish. Bull. 105:313-326.

Bakun, A. (1996) Patterns in the Ocean. Ocean Processes and Marine Population Dynamics. California Sea Grant College System. La Jolla: University of California.

Barton, E.D., Arístegui, J., Tett, P. et al. (1998) The transition zone of the Canary Current upwelling region. Prog. Oceanogr. 41:455-504.

Bécognée, P., Almeida, C., Barrera, A., Hernández-Guerra, A. and Hernández-León, S. (2006) Annual cycle of clupeiform larvae around Gran Canaria Island, Canary Islands. Fish. Oceanogr. 15:293-300.

Bécognée, P., Moyano, M., Almeida, C. et al. (2009) Mesoscale distribution of clupeoid larvae in an upwelling filament trapped by a quasi-permanent cyclonic eddy off Northwest Africa. Deep-Sea Res I 56:330-343.

Benítez- Barrios, V.M.M., Pelegrí, J.L.L., Hernández-Guerra, A. et al. (2011) Three-dimensional circulation in the NW Africa coastal transition zone. Prog. Oceanogr. 91:516-533

Berraho, A. (2007) Relations spatialisees entre miliey et ichthyoplancton des petits pelagiques de la côte atlantique marocaine (zones centrale et sud). Rabat: Université Mohammed V - Agdal.

Bjorkstedt, E.P., Rosenfeld, L.K., Grantham, B.A., Shkedy, Y. and Roughgarden, J. (2002) Distributions of larval rockfishes Sebastes spp. across nearshore fronts in a coastal upwelling region. Mar. Ecol. Prog. Ser. 242:215-228.

Boehlert, G.W., Gadomaski, D.M. and Mundy, B.C. (1985) Vertical distribution of ichthyoplankton off the Oregon coast in spring and summer months. Fish. Bull. 83:611622.

Brochier, T., Ramzi, A., Lett, C. et al. (2008) Modelling sardine and anchovy ichthyoplankton transport in the Canary Current System. J. Plankton Res. 30:1133-1146.

Brochier, T., Colas, F., Lett, C. et al. (2009) Small pelagic fish reproductive strategies in upwelling systems: a natal homing evolutionary model to study environmental constraints. Prog. Oceanogr. 83:261-269.

Brochier, T., Mason, E., Moyano, M. et al. (2011a) Ichthyoplankton transport from the African coast to the Canary Islands: a case study using a high-resolution hydrodynamic model. J. Mar. Syst. 87:109-122.

Brochier, T., Lett, C. and Freon, P. (2011b) Investigating the "northern Humboldt paradox" from model comparisons of small pelagic fish reproductive strategies in eastern boundary upwelling ecosystems. Fish Fish. 14:94-109.

Castro, L.R. and Hernandez, E.H. (2000) Early life survival of the anchoveta Engraulis ringens off central Chile during the 1995 and 1996 winter spawning seasons. Trans. Am. Fish. Soc. 129:1107-1117.

Clarke, K.R. (1993) Non-parametric multivariate analyses of changes in community structure. Aust. J. Ecol. 18:117-143.

Coombs, S., Morgans, D. and Halliday, N. (2001) Seasonal and ontogenetic changes in the vertical distribution of eggs and larvae of mackerel (Scomber scombrus L.) and horse mackerel (Trachurus trachurus L.). Fish. Res. 50:27-40.

Coombs, S.H., Boyra, G., Rueda, L.D. and Uriarte a., Santos M, Conway DVP, Halliday NC, Conwan DVP,, (2004) Buoyancy measurements and vertical distribution of eggs of sardine (Sardina pilchardus) and anchovy (Engraulis encrasicolus). Mar. Biol. 145:959-970.

Cowan, J.H.J. and Shaw, R.F. (2002) Recruitment. In: Fishery science: the unique contributions of early life stages. L.A. 
Fuiman \& R.G. Werner (eds) Oxford: Blackwell Publishing, pp. $88-111$

Cowen, R.K., Lwiza, K.M.M., Sponaugle, S., Paris, C.B. and Olson, R.B. (2000) Connectivity of marine populations: open or closed? Science 287:857-859.

Cury, P. and Roy, C. (1989) Optimal environmental window and pelagic fish recruitment success in upwelling areas. Can. J. Fish. Aquat. Sci. 46:670-680.

Davison, P.C., Checkley, D.M., Koslow, J.A. and Barlow, J. (2013) Carbon export mediated by mesopelagic fishes in the northeast Pacific Ocean. Prog. Oceanogr. 116:14-30.

Ettahiri, O. (1996) Étude de la phase planctonique de la sardine, Sardina pilchardus, et del'anchois, Engraulis encrasicolus, des côtes atlantiques marocaines. Brest: Université de Bretagne Occidentale

Ettahiri, O., Berraho, A., Vidy, G., Ramdani, M. and chi T Do, Ranmdani M,, (2003) Observations on the spawning of sardina and sardinella off the south Moroccan Atlantic coast $\left(21-26^{\circ} \mathrm{N}\right)$. Fish. Res. 60:207-222.

FAO (2009) FAO Fisheries and Aquaculture Information and Statistics Service. Capture production 1950-2007. FISHSTAT Plus - Universal software for fishery statistical time series. Rome: Food and Agriculture Organization of the United Nations.

Field, J.G., Clarke, K.R. and Warwick, R.M. (1982) A practical strategy for analysing multispecies distribution patterns. Mar. Ecol. Prog. Ser. 8:37-52.

Fiksen, $\varnothing$., Jørgensen, C., Kristiansen, T., Vikeb $\varnothing$, F. and Huse, G. (2007) Linking behavioural ecology and oceanography: larval behaviour determines growth, mortality and dispersal. Mar. Ecol. Prog. Ser. 347:195-205.

Fortier, L. and Leggett, W.C. (1983) Vertical migrations and transport of larval fish in a partially mixed estuary. Can. J. Fish. Aquat. Sci. 40:1543-1555

Galarza, J.A., Carreras-Carbonell, J., Macpherson, E. et al. (2009) The influence of oceanographic fronts and early-lifehistory traits on connectivity among littoral fish species. Proc. Natl Acad. Sci. USA 106:1473-1478.

Garijo, J.C., Carlos, J. and López, G. (2011) Zooplankton biomass and abundance in the Coastal Transition Zone off Northwest Africa. Ms Thesis. University of Las Palmas de GC, Las Palmas

Gjosaeter, J. and Kawaguchi, K. (1980) A Review of the World Resources of Mesopelagic Fish. Rome: Food and Agriculture Organization of the United Nations.

Gorbunova, N.N., Evseenko, S.A. and Garetovsky, S.V. (1986) Distribution of ichthyoplankton in the frontal zones of the Peruvian waters. J. Ichthyol. 25:770-782.

Harden-Jones, F.R. (1968) Fish Migration. London: Edward Arnold.

Harrison, C., Siegel, D. and Mitarai, S. (2013) Filamentation and eddy-eddy interactions in marine larval accumulation and transport. Mar. Ecol. Prog. Ser. 472:27-44.

Hernandez, F., Carassou, L., Graham, W. and Powers, S. (2013) Evaluation of the taxonomic sufficiency approach for ichthyoplankton community analysis. Mar. Ecol. Prog. Ser. 491:77-90.

Hernández-León, S., Gómez, M. and Arístegui, J. (2007) Mesozooplankton in the Canary Current System: the coastal-ocean transition zone. Prog. Oceanogr. 74:397-421.

Hutchings, L., Beckley, L.E., Griffiths, M.H., Roberts, M.J., Sundby, S. and Van der Lingen, C. (2002) Spawning on the edge: spawning grounds and nursery areas around the southern African coastline. Mar. Freshw. Res. 53:307318.

Irigoien, X., Cotano, U., Boyra, G. et al. (2008) From egg to juvenile in the Bay of Biscay: spatial patterns of anchovy (Engraulis encrasicolus) recruitment in a non-upwelling region. Fish. Oceanogr. 17:446-462.

Jespersen, P. and Taning, A.V. (1926) Mediterranean Sternoptychidae. Rep Danish Ocean Exped Mediterr 19081910

John, H.C. (1982) Horizontal and vertical distribution of sardine and other fish larvae. Rapp Procès-verbaux Réunion des Cons Int pour l'Exploration la Mer 180:359-364.

John, H.C. (1985) Horizontal and vertical distribution patterns of fish larvae off NW Africa in relation to the environment. In Simposio Internacional sobre las Areas de Afloramiento Más Importantes del Oeste Africano : Cabo Blanco y Benguela. C. Bass, R. Margalef, P. Rubies (eds) Barcelona, Spain: Instituto de Investigaciones Pesqueras, pp. 489-512.

John, H.C. and Kloppmann, M. (1989) Ontogenetic changes in the vertical distribution of larval Maurolicus muelleri (Gmelin, 1789). Arch. für Fischereiwiss. 39:79-93.

Kaartvedt, S., Staby, A. and Aksnes, D. (2012) Efficient trawl avoidance by mesopelagic fishes causes large underestimation of their biomass. Mar. Ecol. Prog. Ser. 456:1-6.

Karnauskas, M., Chérubin, L.M. and Paris, C.B. (2011) Adaptive significance of the formation of multi-species fish spawning aggregations near submerged capes. PLOS ONE 6: e22067.

Koslow, J.A., Goericke, R. and Watson, W. (2013) Fish assemblages in the Southern California Current: relationships with climate, 1951-2008. Fish. Oceanogr. 22:207-219.

Landaeta, M.F. and Castro, L.R. (2013) Vertical distribution and gas bladder inflation/deflation in postlarval anchoveta Engraulis ringens during upwelling events. J. Mar. Biol. Assoc. U. K. 93:321-331.

Lett, C., Roy, C., Levasseur, A., Van der Lingen, C.D. and Mullon, C. (2006) Simulation and quantification of enrichment and retention processes in the southern Benguela upwelling ecosystem. Fish. Oceanogr. 15:363372.

Lindo-Atichati, D., Bringas, F., Goni, G., Muhling, B., MullerKarger, F. and Habtes, S. (2012) Varying mesoscale structures influence larval fish distribution in the northern Gulf of Mexico. Mar. Ecol. Prog. Ser. 463:245-257.

Logerwell, E.A. and Smith, P.E. (2001) Mesoscale eddies and survival of late stage Pacific sardine (Sardinops sagax) larvae. Fish. Oceanogr. 10:13-25.

Logerwell, E.A., Lavaniegos, B. and Smith, P.E. (2001) Spatially-explicit bioenergetics of Pacific sardine in the Southern California Bight: are mesoscale eddies areas of exceptional prerecruit production? Prog. Oceanogr. 49:391406.

Longhurst, A.R. and Williams, R. (1976) Improved filtration systems for multiple-serial plankton samplers and their deployment. Deep-Sea Res. I 23:1067-1073.

Masó, M. and Palomera, I. (1984) Distribución vertical de fases larvarias de peces meso y batipelágicos del Mediterráneo occidental. Investig. Pesq. 48:455-468.

McKelvie, D.S. (1989) Latitudinal variation in aspects of the biology of Cyclothone braueri and C. microdon (Pisces: gonostomatidae) in the eastern North Atlantic Ocean. Mar. Biol. 102:413-424. 
Mittelstaedt, E. (1983) The upwelling area off northwest Africa - a description of phenomena related to coastal upwelling. Prog. Oceanogr. 12:307-331.

Morgan, S.G. and Fisher, J.L. (2010) Larval behavior regulates nearshore retention and offshore migration in an upwelling shadow and along the open coast. Mar. Ecol. Prog. Ser. 404:109-126.

Moser, H. and Smith, P.E. (1993) Larval fish assemblages of the California Current region and their horizontal and vertical distributions across a front. Bull. Mar. Sci. 53:645-691.

Moyano, M. and Hernández-León, S. (2009) Temporal and along-shelf distribution of the larval fish assemblage at Gran Canaria, Canary Islands. Sci. Mar. 73:85-96

Moyano, M. and Hernández-León, S. (2011) Intra- and interannual variability in the larval fish assemblage off Gran Canaria (Canary Islands) over 2005 to 2007. Mar. Biol. 158:257-273.

Moyano, M., Rodríguez, J.M. and Hernández-León, S. (2009) Larval fish abundance and distribution during the late Winter bloom in the Canary Island waters. Fish. Oceanogr. 18:51-61.

Neilson, J.D. and Perry, R.I. (1990) Diel vertical migrations of marine fishes: an obligate or facultative process? Adv. Mar. Biol. 26:115-167.

Norcross, B.L. and Shaw, R.F. (1984) Oceanic and estuarine transport of fish eggs and larvae: a review. Trans. Am. Fish. Soc. 2113:153-165.

Olivar, M.P. and Sabates, A. (1997) Vertical distribution of fish larvae in the North-west Mediterranean Sea in spring. Mar. Biol. 129:289-300.

Olivar, M.P., Rubies, P. and Salat, J. (1992) Horizontal and vertical distribution patterns of ichthyoplankton under intense upwelling regimes off Namibia. S. Afr. J. Mar. Sci. 12:71-82.

Olivar, M.P., Salat, J. and Palomera, I. (2001) Comparative study of the spatial distribution patterns of the early stages of anchovy and pilchard in the NW Mediterranean Sea. Mar. Ecol. Prog. Ser. 217:111-120.

Olivar, M.P., Emelianov, M., Villate, F. et al. (2010) The role of oceanographic conditions and plankton availability in larval fish assemblages off the Catalan coast (NW Mediterranean). Fish. Oceanogr. 19:209-229.

Palomera, I. and Rubies, P. (1982) Kinds and distribution of fish eggs and larvae off Northwest Africa in April/May 1973. Rapp Proc Verb Réunions Cons int l'Expl Mer 180:356-358.

Parrish, R.H., Nelson, C.R. and Bakun, A. (1981) Transport mechanisms and reproductive success of fishes in the California Current. Biol. Oceanogr. 1:175-203.

Queró, J.C., Hureau, J.C., Karrer, C., Post, A. and Saldanha, L. (1990) Check List of the fishes of the Eastern Tropical Atlantic. Lisbon: JNICT; Paris: SEI; Paris: UNESCO.

Richardson, S.L. and Pearcy, W.G. (1977) Coastal and oceanic fish larvae in an area of upwelling off Yaquina Bay, Oregon. Fish. Bull. 75:125-145.

Rodríguez, J.M., Barton, E.D., Hernandez-Leon, S. and Aristegui, J. (2004) The influence of mesoscale physical processes on the larval fish community in the Canaries-CTZ, in summer. Prog. Oceanogr. 62:171-188.

Rodríguez, J.M., Hernandez-Leon, S. and Barton, E.D. (2006) Vertical distribution of fish larvae in the Canaries-African coastal transition zone in summer. Mar. Biol. 149:885-897.

Rodríguez, J.M., Gonzalez-Pola, C., Lopez-Urrutia, A. and Nogueira, E. (2011) Composition and daytime vertical distribution of the ichthyoplankton assemblage in the Central Cantabrian Sea shelf, during summer: an Eulerian study. Cont. Shelf Res. 31:1462-1473.

Rodríguez, J.M., Hernández-León, S. and Barton, E.D. (1999) Mesoscale distribution of fish larvae in relation to an upwelling filament off Northwest Africa. Deep-Sea Res. I 46:1969-1984.

Rodríguez, J.M., Braun, J.G. and García, A. (2000) Spatial variability of the mesozooplankton biomass and ichthyoplankton in the Canary region, in autumn 1991. J. Plankton Res. 22:1377-1391.

Rodríguez, J.M., Barton, E.D., Eve, L., Hernández-León, S. and Hern, S. (2001) Mesozooplankton and ichthyoplankton distribution around Gran Canaria, an oceanic island in the NE Atlantic. Deep-Sea Res. I 48:2161-2183.

Rodríguez, J.M., Moyano, M. and Hernández-León, S. (2009) The ichthyoplankton assemblage of the Canaries-Africa coastal transition zone: a synthesis. Prog. Oceanogr. 83:314-321.

Rojas, P.M., Escribano, R. and Marín, V.H. (2002) Fish larvae distribution off Mejillones Peninsula (northern Chile) during a coastal upwelling event in Spring 1999: interactions with the cold upwelling plume. Fish. Oceanogr. 11: 233-244.

Sabatés, A. and Olivar, M.P. (1996) Variation of larval fish distributions associated with variability in the location of a shelf-slope front. Mar. Ecol. Prog. Ser. 135:11-20.

Sabatés, A., Zaragoza, N. and Grau, C. (2008) Vertical distribution of early developmental stages in two coexisting clupeoid species, Sardinella aurita and Engraulis encrasicolus. Mar. Ecol. Prog. Ser. 364:169-180.

Sabatés, A., Salat, J., Raya, V. and Emelianov, M. (2013) Role of mesoscale eddies in shaping the spatial distribution of the coexisting Engraulis encrasicolus and Sardinella aurita larvae in the northwestern Mediterranean. J. Mar. Syst. 111112:108-119.

Smith, P.E. and Richardson, S.L. (1977) Standard techniques for pelagic fish egg and larva surveys. FAO Fish Tech Pap 175:100 p.

Stenevik, E.K., Skogen, M., Sundby, S. and Boyer, D. (2003) The effect of vertical and horizontal distribution on retention of sardine (Sardinops sagax) larvae in the Northern Benguela - observations and modelling. Fish. Oceanogr. 12:185-200.

Stenevik, E., Sundby, S. and Cloete, R. (2007) Diel vertical migration of anchovy Engraulis encrasicolus larvae in the northern Benguela. Afr. J. Mar. Sci. 29:127-136.

Wienerroither, R.M. (2005) Meso- and bathypelagic fishes of the Canary Islands: an annotated species list, species composition, and biogeographic distribution. University of Salzburg 